\title{
31. SURFICIAL GEOLOGY OF THE CONTINENTAL MARGIN OFFSHORE NEW JERSEY IN THE VICINITY OF DEEP SEA DRILLING PROJECT SITES 612 AND 613 1
}

\author{
John A. Farre and William B. F. Ryan, Lamont-Doherty Geological Observatory²
}

\begin{abstract}
A dense grid of near-bottom Sea MARC $130-\mathrm{kHz}$ sidescan and $4.5-\mathrm{kHz}$ sub-bottom sonar data, high-resolution air-gun seismic reflection profiles, seafloor photographs, and drill data have been used to study the near-surface geology of a $30 \times 30 \mathrm{~km}$ segment of the New Jersey continental margin containing DSDP Sites 612 and 613 . On the basis of age and acoustic properties, 16 surficial sedimentary units have been defined and mapped.

The continental margin is separated into three distinct provinces: the upper and middle continental slope; the lower continental slope; and the upper continental rise. The upper and middle continental slope is covered by terrigenous Quaternary sediment and is incised by $\mathrm{U}$ - to $\mathrm{V}$ - shaped (in cross section) canyons and valleys which die out on the lower slope. Areas of the upper and middle slope not incised by canyons also show evidence of significant, geologically recent, downslope-directed erosion. The surficial lower continental slope consists almost exclusively of rugged exposures of middle Eocene biosiliceous limestone. In the southwestern part of the lower slope, two lower slope canyon systems begin in water depths of $1500-1600 \mathrm{~m}$. They have steep, joint-controlled bounding walls and broad floors that coincide with bedding planes in the Eocene section. We argue that these canyons formed mainly by the removal of joint- and bedding plane-bound slabs of strata by downslope-directed currents during the Pleistocene. The eastern portion of the lower slope is composed of gently seaward-dipping surfaces, which coincide with Eocene bedding, offset by steep, fewmeter-high scarps, which step down deeper into the stratigraphic section. Also present in this area are numerous downslope-trending grooves, a few meters deep and wide, which we interpret to be mega gouge marks cut into the exposed limestones during rock and sediment slides.

Terrigenous deposits of the upper continental rise onlap the erosional surface of the lower continental slope. An abrupt decrease in seafloor gradient $\left(4.5\right.$ to $\left.1.5^{\circ}\right)$ marks the continental slope/rise boundary. Three oblong topographic depressions, 30-70 m deep and a few kilometers wide and long, are excavated into the upper continental rise. They range from being empty to nearly filled by horizontally bedded strata which are interpreted to be mass flow deposits derived from the slope. Immediately landward of one depression, on the lowermost slope, are a series of rock-slide scars which appear fresh on sidescan and sub-bottom profiles. Seaward of this depression are downslope-trending shallow channels, allochthonous debris and one large block (several meters in diameter) which has skidded $>4 \mathrm{~km}$ downslope across the $1.5^{\circ}$ gradient of the upper continental rise, leaving a clearly defined trail. The depressions are apparently eroded as downslope-directed mass flows encounter the abrupt gradient reduction at the slope/rise boundary.

Prior to the late Miocene, significant erosion exposed semi-lithified middle Eocene rocks that have apparently remained exposed to the present day. Although this event (or events) cannot be precisely dated, we present two possible mechanisms for the initiation of lower slope erosion during the Oligocene. Subsequent slope erosion has prevented significant sediment from accumulating above this major erosional surface. Only through the process of continental rise onlap has sediment accumulated to significant thickness above the major unconformity.

Approximately two-thirds of the study area is now draped by a $1-$ to $3-\mathrm{m}$ thick hemipelagic deposit of late Pleistocene-Holocene age. While the magnitude and frequency of downslope-directed sediment transport and erosion may have decreased since the late Pleistocene, the remotely-sensed data indicate that these processes have not altogether ceased.

Results from our detailed study indicate that sites for stratigraphic sampling on continental slopes must be chosen very carefully, if the most complete stratigraphic sections are desired. Margins of submarine canyons may be the preferred locations, because most downslope-directed and potentially erosive flows tend to follow down canyon thalwegs, leaving canyon margins relatively undisturbed.
\end{abstract}

\section{INTRODUCTION}

In this chapter, we present results from an investigation of a $30 \mathrm{~km} \times 30 \mathrm{~km}$ area of the U.S. Atlantic continental margin offshore New Jersey that contains DSDP Leg 95 Sites 612 and 613 . The area contains a variety of underwater landscapes with submarine canyons and open slope settings. On the lower continental slope, extensive outcrops of early Tertiary rock are onlapped by a lower gradient continental rise prism.

\footnotetext{
${ }^{1}$ Poag, C. W., Watts, A. B., et al., Init. Repts. DSDP, 95: Washington (U.S. Govt, Printing Office).

2 Addresses: (Farre, present address) Exxon Production Research Co., P.O. Box 2189, Houston TX, 77252-2189; (Ryan) Lamont-Doherty Geological Observatory and Dept. of Geological Sciences, Columbia University.
}

The area is particularly well suited for the deciphering of Cenozoic history. Data from numerous boreholes are available to the scientific community. Because the area has been a target of hydrocarbon exploration, seismic data gathered at great effort by the United States Geological Survey (U.S.G.S.) to assess environmental hazards (Robb, 1980) are available to the public. Such data are especially useful because the generally thin accumulation of Neogene sediment allows the high-resolution reflection profiling to penetrate the entire Cenozoic section.

Overlapping mid-range sidescan-sonar coverage and a closely spaced net of high-resolution shallow penetration sub-bottom profiles provide a detailed perspective of seafloor morphology and the sedimentary processes 
that have shaped this margin during the recent geologic past. It is through the integration of data sets with such different degrees of resolution, calibrated to detailed stratigraphic sampling, that a more thorough understanding of the evolution of passive continental margins can be obtained.

This chapter emphasizes the near-surface (few tens of meters) stratigraphy and structure of the study area. For this purpose, the high-resolution U.S.G.S. seismic profiles were used mainly to extrapolate the drill data and date the surficial deposits. A more complete analysis of the high-resolution seismic profiles is presented by Robb, Hampson, Kirby, et al. (1981), Robb, Hampson and Twichell (1981), Farre (1985); and Poag and Mountain (this volume).

\section{Regional Setting}

The continental margin offshore New Jersey is composed of a thick accumulation of sediment known as the Baltimore Canyon Trough (BCT). The trough, one of several buried shelf basins found along the U.S. Atlantic margin, is separated from the Georges Bank Basin by the Long Island Platform to the north and from the Carolina Trough by the Carolina Platform to the south (Klitgord and Behrendt, 1979; Folger, et al., 1979).

As much as $14 \mathrm{~km}$ of sediment have accumulated in the BCT since the onset of continental rifting in the late Triassic (Schlee et al., 1976; Schlee, 1981; Poag, 1985a). Lying unconformably above crystalline rocks of the Applachian Fold Belt, the landward-thinning edge of BCT sediments lie exposed along Maryland and New Jersey forming the Atlantic Coastal Plain (ACP), (Murray 1961, fig. 1). Seaward of the feather edge of the ACP, the sedimentary section abruptly thickens. The region of most rapid basement deepening is known as the hinge zone (e.g., Watts and Steckler, 1979, Fig. 1).

\section{METHODS}

\section{Field Programs}

\section{Sea MARC I}

The Sea MARC I data presented in this chapter were collected as part of the East Coast Hazards Observation (ECHO) Project in May 1981. The main objective of this industry-sponsored program was to demonstrate the capability of existing deep-water survey technology of providing data on environmental hazards to hydrocarbon exploration. The project, managed and directed by Shell Development Co., employed high-resolution seismic profiling, $30-\mathrm{kHz}$ sidescan-sonar (Sea MARC I), 100-kHz sidescan sonar, and limited piston coring. The Sea MARC I survey was performed by personnel from Lamont-Doherty Geological Observatory (L-DGO) with technical assistance from International Submarine Technology, Racal-Decca Surveys Inc., and Edo Western Corp. Results of the project have been presented by Farre and Ryan (1983 1985a), Prior et al. (1984), and Prior and Doyle (1984, 1985).

\section{Seafloor Photos}

Three seafloor camera tows through the study area were conducted in May 1981 by L-DGO personnel. They used an autonomous camera system that takes a seafloor photo every $15 \mathrm{~s}$ obliquely in front of a slowly moving $(75 \mathrm{~cm} / \mathrm{s})$ camera sled for nearly complete photographic coverage (see Chayes et al., 1984). The purpose of the photo transects was to study the distribution of benthic organisms in canyon and open slope settings as well as to identify fragile communities that might become endangered as hydrocarbon exploration activities intensify. The studies were funded by the Minerals Management Service of the Bureau of Land Management, and results have been presented by Hecker et al. (1983).

\section{Alvin Dives}

Four Alvin dives in the vicinity of the study area (Dives 1112, 1113 and 1115 within the study area, and Dive $1117 \sim 5 \mathrm{~km} \mathrm{NE}$ of the study area on the lower continental slope) were carried out in July 1981 in a cooperative effort between U.S.G.S. and L-DGO scientists. The objectives of the dives were to "ground-truth" an earlier Sea MARC I survey conducted jointly by U.S.G.S. and L-DGO (e.g., Robb, Hampson, and Twichell, 1981b; Ryan, 1982; Farre et al., 1983) and to study the benthic megafauna. Results from these Alvin dives have been presented by Robb et al. (1983), Hecker et al. (1983), and Robb (1984). An earlier series of Alvin dives were carried out in 1975 and 1976, with funding from the U.S. Environmental Protection Agency, at Deep Water Radioactive Dumpsite 106 (Rawson and Ryan, 1978). The dumpsite is $\sim 10 \mathrm{~km} \mathrm{NE}$ of the Sea MARC I study area on the upper continental rise.

\section{Seismic Data}

Single-channel air-gun seismic reflection profiles were collected in June/July 1979 by the U.S.G.S. (Robb, 1980). Results from this project have been presented by Robb, Hampson, Kirby, et al. (1981), Robb, Hampson, and Twichell (1981), Farre (1985), and Poag and Mountain (this volume). We purchased these data from the National Geophysical and Solar-Terrestrial Data Center (NGSDC), Boulder, Colorado 80303.

\section{Drilling Program and Results}

Drill sites that lie within the study area (Fig. 1) are stratigraphic ground-truth data for the Sea MARC I data and high-resolution seismic profiles.

In 1967, the first stratigraphic drilling program on the U.S. midAtlantic margin was sponsored by a group of oil companies to assess the sedimentary framework of the BCT. The Atlantic Slope Project (ASP) drilled seven shallow $(<300 \mathrm{~m})$ cores on the continental slope: two of which lie within the study area (Poag, 1985a). ASP-14 (1191 m water depth) penetrated $300 \mathrm{~m}$ into Pleistocene, middle Miocene, and lower Miocene silty and sandy mudstone. ASP-15 (1493 m water depth) penetrated $230 \mathrm{~m}$ into Pleistocene, middle Miocene, lower Miocene, Oligocene, upper Eocene, middle Eocene, and lower Eocene strata.

In 1970, on DSDP Leg 11, Site 108 sampled middle Eocene biosiliceous chalk at $1855 \mathrm{~m}$ on the lower continental slope (Hollister et al., 1972). Drilling difficulties resulted in abandonment of the hole after only $40 \mathrm{~m}$ of sample recovery.

The COST B-3 well was the first deep stratigraphic test well to be drilled on the U.S. mid-Atlantic continental slope (Scholle, 1980). It reached $4003 \mathrm{~m}$ below the seafloor in a water depth of $819 \mathrm{~m}$. Drilling procedures prevented data recovery above $312 \mathrm{~m}$ sub-bottom where middle Miocene sands, silts, and clays were encountered.

A velocity survey log was conducted at the COST B- 3 site in which a hydrophone was lowered down the hole and an acoustic source was fired at the drill ship (Carlson, 1979). This established a direct link between two-way acoustic traveltime and depth in meters beneath the sea surface. This log has been very helpful in calibrating the results from COST B-3 to the seismic grid.

DSDP Sites 604 and 605 were drilled on the upper continental rise within the study area (van Hinte, Wise, et al., 1985). Site 604 (2364 m water depth) was terminated at $295 \mathrm{~m}$ sub-bottom because of difficulty in penetrating upper Miocene sandy deposits. Site 605 (2197 m water depth) was drilled $7 \mathrm{~km} \mathrm{NW}$ of Site 604 where seismic data predicted that the Miocene sands would be absent. The uppermost section at Site 605 consists of $198 \mathrm{~m}$ of Quaternary silty-clay, $0.14 \mathrm{~m}$ of late Pliocene clay, $152 \mathrm{~m}$ of lower middle Eocene chalk.

The most recent drilling program on the U.S. mid-Atlantic margin was DSDP Leg 95, which completed two holes within the study area: Site 612 (1404 m water depth) on the middle continental slope and Site 613 ( $2323 \mathrm{~m}$ water depth) on the upper continental rise (Leg 95 Scientific Party, 1984; Poag, 1985 a,b; Site 612 and 613 chapters, this volume).

Site 612 was inadvertently drilled at the site of a buried canyon which accounts for the unusually long ( $25 \mathrm{~m}$.y.) hiatus represented by the unconformity separating upper Miocene terrigenous deposits from underlying upper Eocene-lowermost Oligocene chalks (Farre, 1985; 


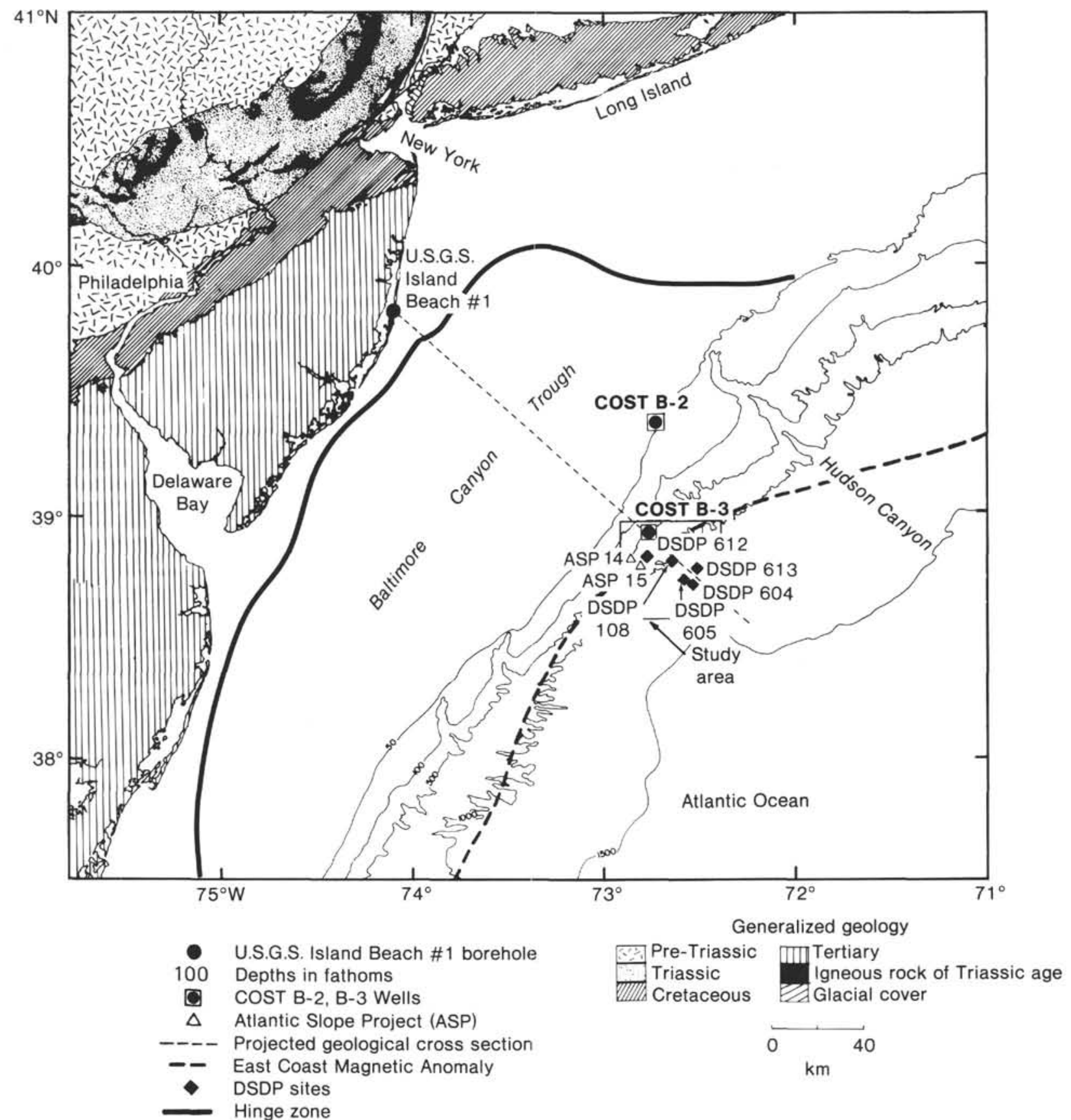

Figure 1. Map showing the regional setting of the U.S. Mid-Atlantic Margin. Modified from Watts (1981).

Poag and Mountain, this volume). Nevertheless, strata penetrated at this site provide important age constraints to the seismic profiles that cross the middle slope.

Site 613 , on the upper continental rise, penetrated three distinct lithologic units (Poag, 1985b; Site 613 chapter, this volume). The uppermost unit is composed of $270 \mathrm{~m}$ of interbedded silts, sands, and clays which comprise the Quaternary-Miocene continental rise. This unit onlaps and lies unconformably above the seaward-dipping middle Eocene erosional surface.

\section{Techniques}

\section{Sea MARC I}

More than $500 \mathrm{~km}^{2}$ of the mid-Atlantic continental margin were investigated with Sea MARC I sidescan-sonar coverage at both 1- and 5-km swath widths. Thirty-seven near-bottom survey lines cross the area at an average spacing of $1 \mathrm{~km}$ (Fig. 2). Ship navigation used LORAN-C, calibrated to a Decca Hi-Fix range-range radio positioning system. Fish navigation was done acoustically, relative to the ship. We employed a prototype of a short-baseline vehicle tracking system (Edo Western Navtrak). Two ship-mounted transducers measure the traveltime and acoustic phase angle of incomming $12-\mathrm{kHz}$ pings from the vehicle. By comparing the phase, an azimuth from the ship to vehicle is determined. This azimuth, along with velocity-corrected slant range (acoustically determined straight-line distance between ship and vehicle), ship heading, and vehicle depth determine each vehicle fix. The system worked satisfactorily, except in rough seas, but hand editing and smoothing of the azimuth data were necessary. Tracklines were then adjusted to ensure agreement on sidescan images at track intersections. From the study of sidescan track crossings, we estimate the 


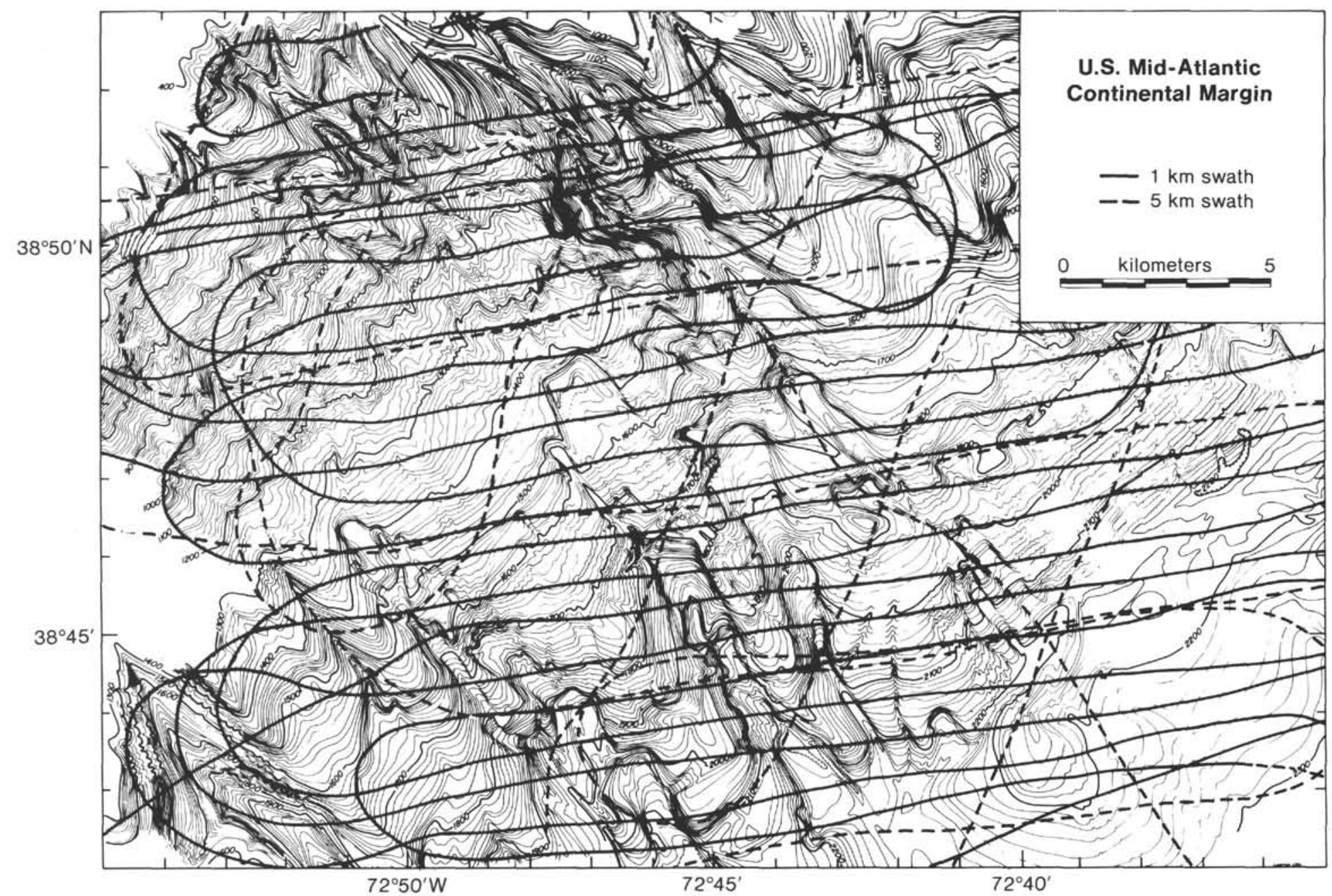

Figure 2. Location map of Sea MARC I vehicle tracks in the study area. 
relative navigation uncertainty of the adjusted Sea MARC I vehicle track to correspond to a distance that is less than $5 \%$ of the water depth.

Vehicle depth was measured by a sensitive pressure gauge with a $0.2 \mathrm{~m}$ resolution, and along with vehicle altitude, was logged on magnetic tape every transmit cycle $(1,2$, or $4 \mathrm{~s})$. At typical towing speeds of $3.5 \mathrm{~km} / \mathrm{hr}$., a water depth was logged for every $1-4 \mathrm{~m}$ advancement of the sonar vehicle. The pressure depth was converted to acoustic depth using a function determined by measuring echo returns bounced from the sea surface.

A bathymetric map was constructed from the near-bottom echo sounding at a scale of 1:40000 (Fig. 3). The map incorporates $4.5-\mathrm{kHz}$ data from 37 Sea MARC I tracks. Water depth was obtained by adding the acoustically determined vehicle altitude to the vehicle acoustic depth. The contoured depth is in meters, based on the sonic velocity in water of $1500 \mathrm{~m} / \mathrm{s}$. Fine-scale detail of the bathymetric map was added by adjusting the contours between tracks by interpreting highlights and shadows from the sidescan images.

\section{Seafloor Photographs}

The navigation for the L-DGO bottom photograph transects had not been fully completed. This is because the biologists were not as interested in exact photo locations as they were with the water depth (annotated on each frame) associated with the various biological assemblages. Using the depths and bathymetric features recorded on the bottom photographs, camera vehicle tracks were constructed directly on the detailed bathymetric map (Fig. 4).

\section{Alvin Dives}

The Alvin dive tracks were plotted on our bathymetric base map. Minor translations to the dive tracks (order of $100 \mathrm{~m}$ ) were necessary to provide agreement between features seen on the bow camera footage and described in the written transcripts and the bathymetric map (Fig. 4).

\section{Seismic Data}

The single-channel air-gun seismic data were delivered in microfilm form. They were reproduced onto semitransparent Velum paper and then copied on an Ozalid machine to provide work copies for tracing seismic reflectors. The data were filtered aboard ship with a bandpass of $70-150 \mathrm{~Hz}$, resulting in a concentration of acoustic energy on the records at wavelengths of $10-20 \mathrm{~m}$. The profiles are spaced $1 \mathrm{~km}$ between dip lines and 2-3 km between strike lines (Fig. 5).

The velocity survey log and the biostratigraphic data from the COST B-3 well are the essential link between the seismic and age data. U.S.G.S. dip Line 77 crosses directly over the COST B-3 site, thus eliminating difficulties inherent in projecting borehole data several kilometers or more to nearby seismic lines (e.g., Taylor and Anderson, 1980). (Areas shown by figures in this chapter are indicated on the map in Figure 6.)

Table 1 lists the chronostratigraphic units identified at the COST B-3 site, along with the round-trip acoustic traveltime to their lower boundaries and their calculated average interval velocities. The Pliocene/upper Miocene and upper/middle Miocene boundaries were not sampled at the COST B-3 well. Their boundaries are tentative, based on the integration of data from the other stratigraphic sample locations. Figure 7 is the interpreted depth section corresponding to seismic dip Line 77.

\section{DATA PRESENTATION}

In this chapter, the continental slope is divided into three sections: the upper slope $(200-900 \mathrm{~m})$, the middle slope (900-1500 m), and the lower slope (1500-2200 m). A submarine canyon is meant to denote an erosional system at least $100 \mathrm{~m}$ deep, cut into the continental margin. It must extend landward to near the shelf break and down at least onto the lower continental slope. A canyon can have a $\mathrm{V}$-shaped or $\mathrm{U}$-shaped profile in cross section. A valley is a general term used to denote a significant downslope-trending erosional feature of the continental slope. A gully is a short $(<2 \mathrm{~km})$ erosional incision on a steep slope that commonly feeds canyons. In this chapter, a lower slope canyon is a steep-walled, flatfloored excavation into the lower continental slope primarily cut into Eocene strata. It has relief of $>50 \mathrm{~m}$ and does not extend significantly up onto the middle continental slope.

\section{Near-Bottom 4.5-kHz Reflection Stratigraphy}

Acoustic penetration of Sea MARC I's near-bottom sub-bottom profiler ranged from $<1 \mathrm{~m}$ in reverberent substrates to as great as $65 \mathrm{~m}$ in hemipelagic Quaternary deposits. Sixteen stratigraphic units are defined on the basis of the acoustic properties of penetration, surface and sub-bottom reflectivity, degree of stratification, and age (Table 2). Sidescan reflectivity, to a lesser extent, aids the classification process. Ground truth and age assignment is accomplished by calibration to drill sites (i.e., COST B-3, DSDP Sites 108, 612, and 613), shallow cores from the Atlantic Slope Project (Fig. 1), seafloor photographs from the L-DGO unmanned vehicle, and photographs and written transcripts from DSRV Alvin Dives 1112,1113 , and 1115 (Fig. 4). The drill, core, and photographic data were used to calibrate the single-channel seismic data collected by the U.S.G.S. in 1979. The highresolution U.S.G.S. seismic data, in addition to Sea MARC I 4.5-kHz sub-bottom data, allow extrapolation of these data to provide ages for the surficial sedimentary units throughout the study area (Fig. 8). This map shows a distribution of surficial strata similar to that of Hampson and Robb (1984), but the new map shows more detail as it incorporates the newly acquired ECHO highresolution Sea MARC I data set and preliminary results from DSDP Leg 95.

An important 1 to 3-m thick acoustically transparent sediment drape is detectable on sub-bottom records over approximately two-thirds of the study area. It is interpreted to be a hemipelagic deposit that began accumulating near the end of the last glacial cycle. Carbon-14 dates from drop cores (Prior et al., 1984), indicate that the drape is latest Pleistocene to Holocene in age. This thin cover is referred to in the following sections as Holocene drape, but it may extend back into the latest Pleistocene.

There can be ambiguity in discriminating between the Holocene drape and thin debris flow deposits (e.g., Embley, 1976). Although both can be acoustically transparent, debris flow deposits tend to exhibit greater variability in thickness and their hummocky upper surfaces do not in general mimick underlying topography. Nonetheless, in some cases in the floors of canyons on the slope and in places on the rise, one cannot be sure that all areas identified as Holocene drape are not thin, gravitycontrolled debris flow deposits.

Table 2 is a summary of the 16 acoustic units. For a more complete description, see Farre (1985).

\section{Seafloor Morphology}

Based on the contours of the bathymetric map (Fig. 3 ), the continental margin can be separated into three distinct areas: the upper and middle continental slope, the lower continental slope, and the upper continental rise. The upper and middle slope are characterized by $\mathrm{V}$ - 


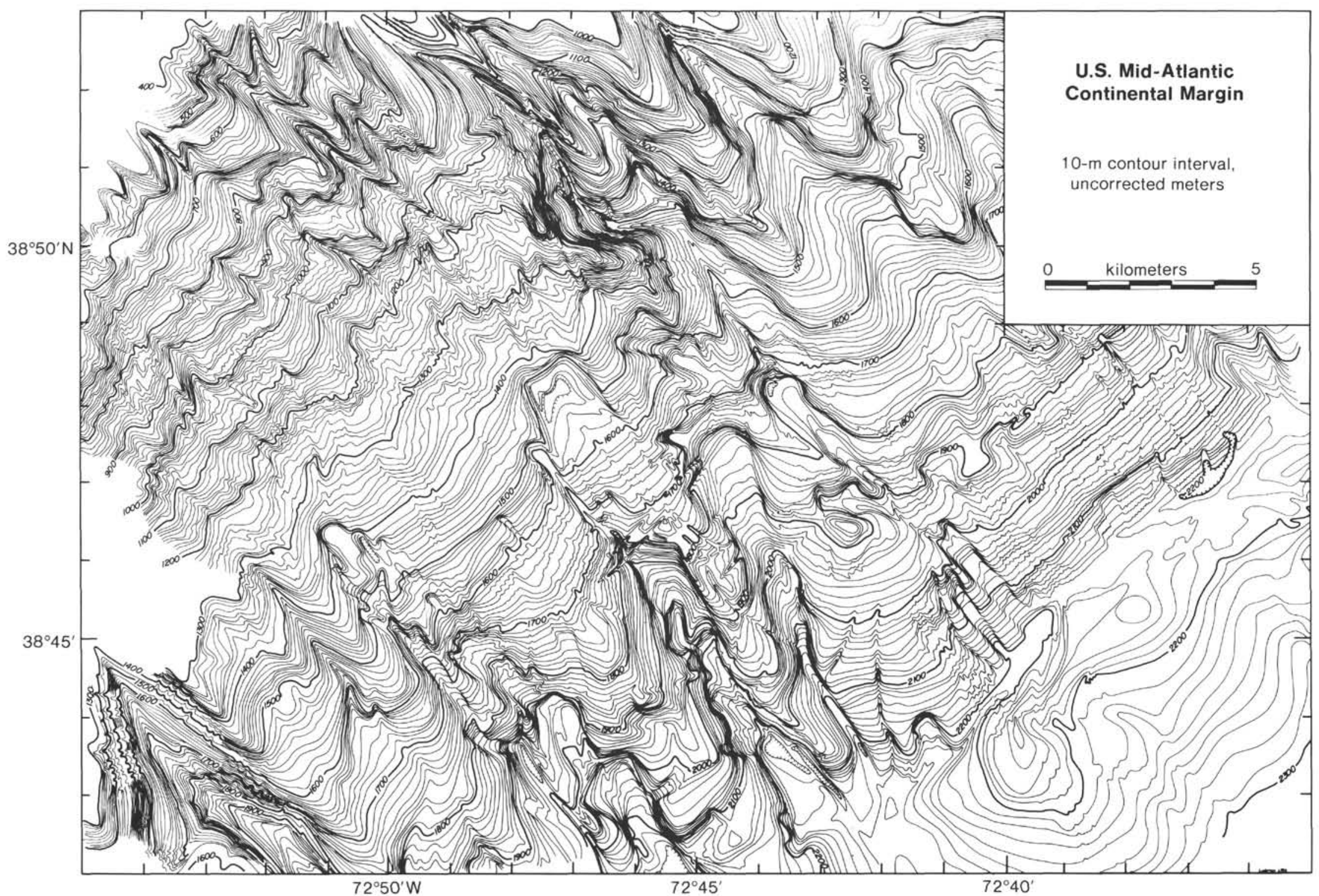

Figure 3. Bathymetry map of the study area based on near-bottom $4.5-\mathrm{kHz}$ data from 37 Sea MARC I tracklines. Contours are adjusted between tracklines by interpreting highlights and shadows depicted on the sidescan-sonar images. Modified from Farre and Ryan (1985a). 


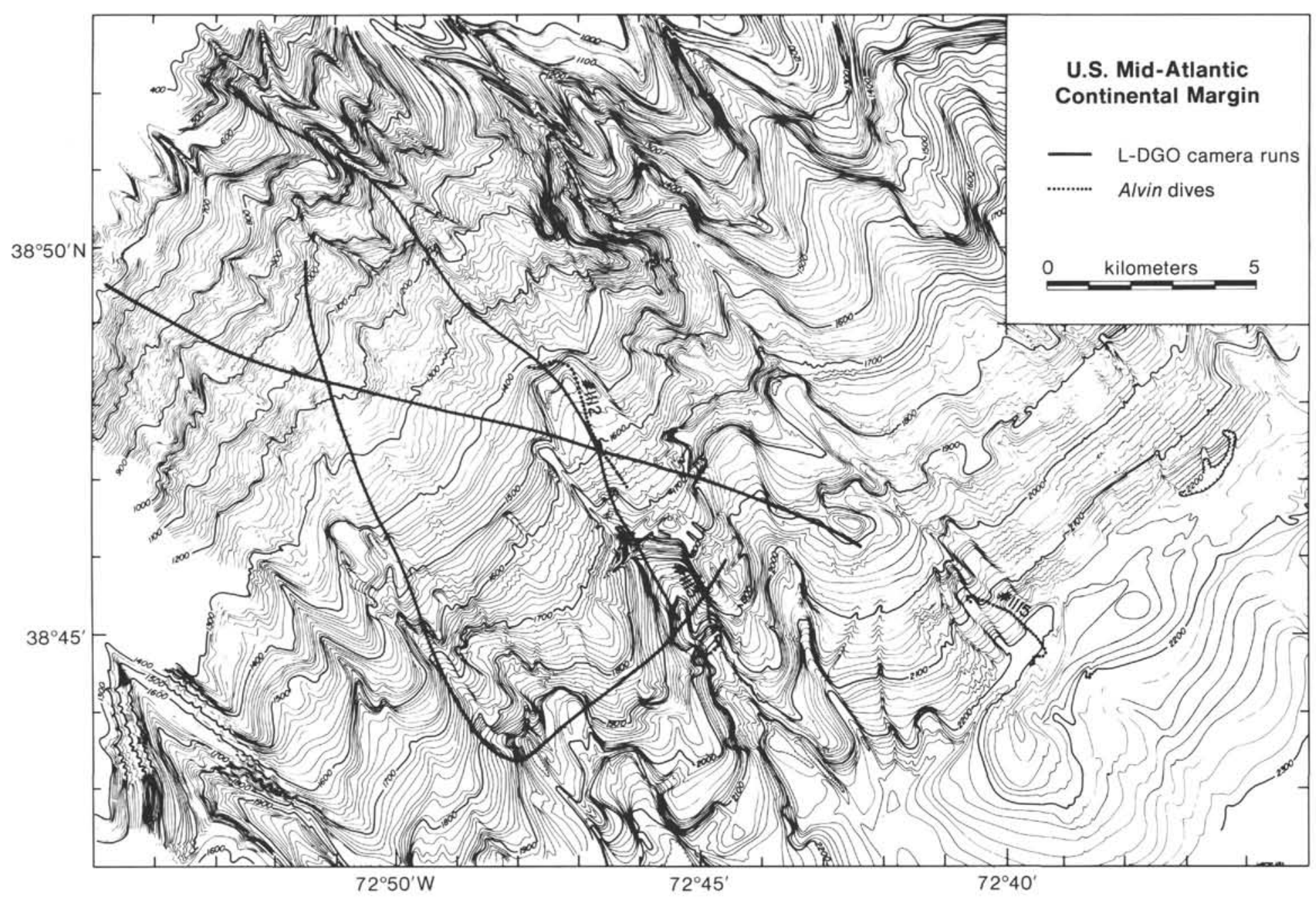

Figure 4. Location map of the unmanned L-DGO camera survey lines and Alvin dive tracks. 


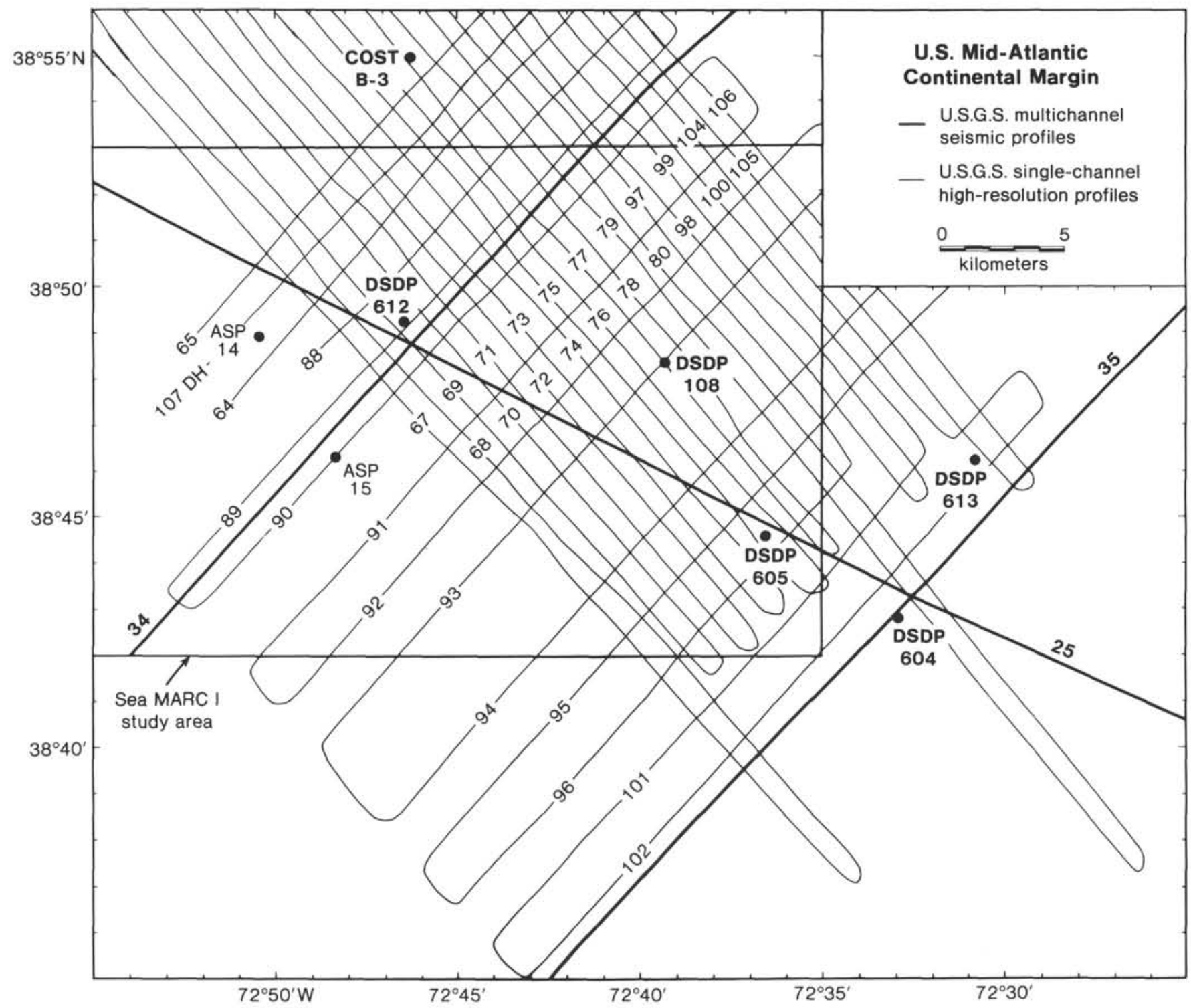

Figure 5. Location map of the high-resolution seismic profiles collected by the U.S.G.S. in 1979 (Robb, 1980) and examined in this study.

shaped contours delineating continuous valleys and canyons. On the upper and middle slope, there is a substantial drape of unconsolidated Quaternary sediment (Units $\mathrm{Q} 1$ and P1). The V-shaped valleys and canyons both incise and are sometimes draped on their walls by these strata. The lower slope is characterized by broader, flatfloored canyons that generally have steep headwalls at depths of $1500-1600 \mathrm{~m}$. The headwalls generally correlate to the depth interval at which the top of the Eocene section is either exposed or buried in the shallow subsurface.

The transition from lower slope to uppermost continental rise is sharp and it is marked by an abrupt change in gradient (from 4.5 to $1.5^{\circ}$ ) at $2200 \mathrm{~m}$. The uppermost rise is characterized by a regional smoothness not seen on the slope.

\section{Submarine Canyons}

Three submarine canyons in the study area cross all or most of the continental slope. In order of size they are: Lindenkohl, Carteret, and a unnamed canyon adjacent to the NE of Carteret Canyon (informally named North Carteret Canyon, Fig. 9). Lindenkohl Canyon significantly indents the shelf break and continues out across the continental rise (Twichell and Roberts, 1982). Carteret Canyon barely indents the shelf break and North Carteret Canyon does not reach the shelf break (Kirby et al., 1982). Carteret and North Carteret canyons do not reach the continental rise as continuous incisions. NE of North Carteret Canyon is a shallower ( $<200 \mathrm{~m}$ deep), broader valley (informally named Northeast Valley) which begins on the upper slope and dies out on the lower slope in a manner similar to North Carteret Canyon.

\section{Lindenkohl Canyon}

Because Lindenkohl Canyon lies at the western boundary of the study area, most of the data for this canyon were collected during turns and coverage of the canyon is incomplete. 


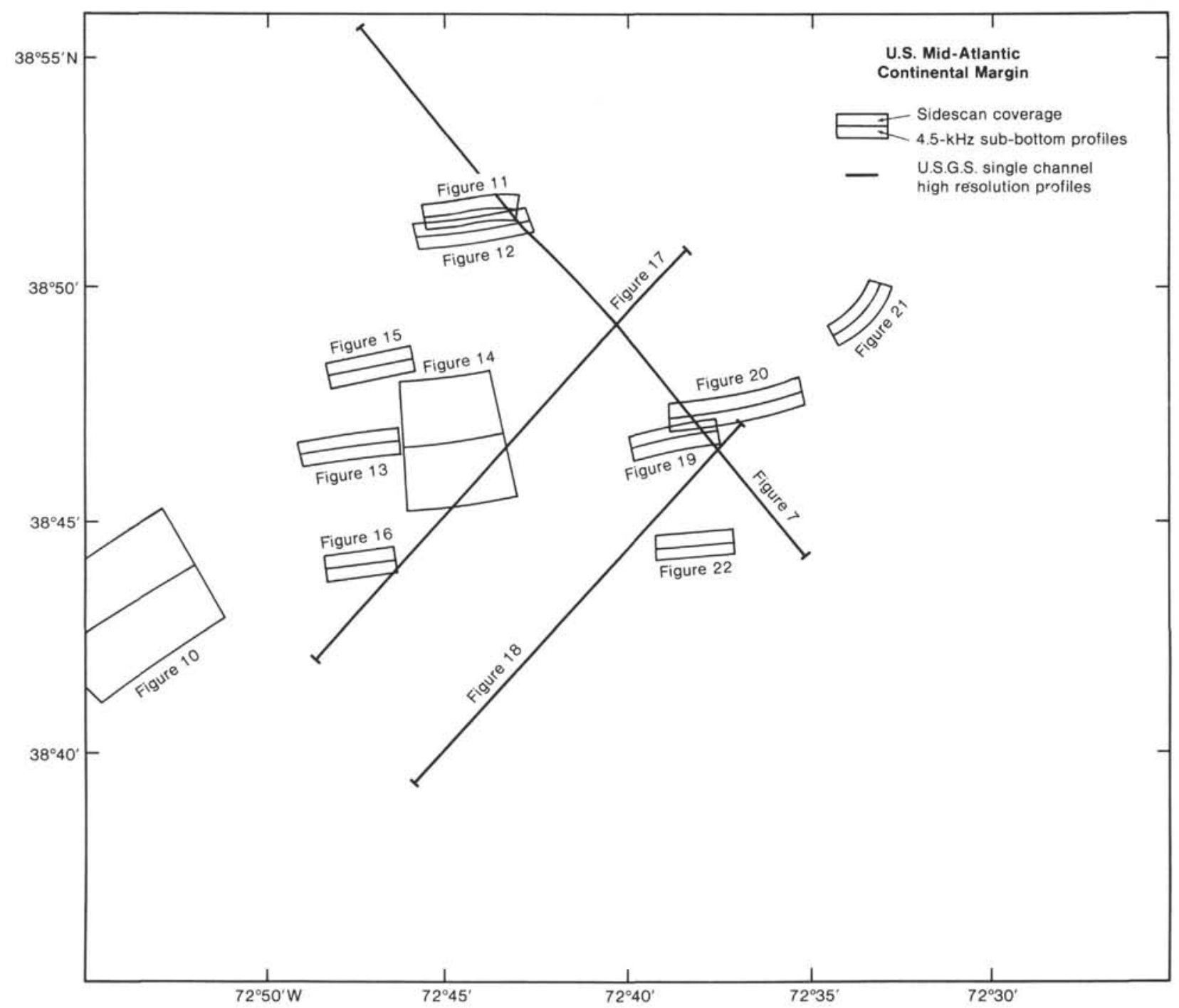

Figure 6. Map showing figure locations.

Table 1. COST B-3 velocity data.

\begin{tabular}{|c|c|c|c|}
\hline Unit age & $\begin{array}{l}\text { Unit } \\
\text { thickness } \\
\text { (m) }\end{array}$ & $\begin{array}{l}\text { Two-way } \\
\text { traveltime to } \\
\text { base of unit } \\
\text { (s) }\end{array}$ & $\begin{array}{l}\text { Interval } \\
\text { velocity }\end{array}$ \\
\hline Holocene-Pliocene & 185 & 1.32 & 811 \\
\hline upper Miocene & 105 & 1.45 & 807 \\
\hline middle Miocene & 275 & 1.78 & 833 \\
\hline lower Miocene & 65 & 1.84 & 1083 \\
\hline upper Oligocene & 95 & 1.92 & 1187 \\
\hline upper Eocene & 70 & 1.99 & 1000 \\
\hline middle Eocene & 80 & 2.07 & 1000 \\
\hline lower Eocene & 125 & 2.18 & 1136 \\
\hline upper Paleocene & 50 & 2.22 & 1250 \\
\hline
\end{tabular}

a The unit thicknesses (except for the Holocene-upper Miocene section thicknesses, which were arrived at from the seismic analysis) are from figure 6-2 (Foldout) of Poag (1985a).

b Two-way traveltime and interval velocity were determined from the velocity survey $\log$ (Carlson, 1979).
Sidescan images show the presence of numerous side gullies incising the walls of Lindenkohl Canyon (Fig. 10). The gullies and the spurs between them are up to $1 \mathrm{~km}$ long, and sidescan shadows indicate that they are usually less than $20 \mathrm{~m}$ deep. They intersect the canyon at acute angles ranging from 70 to $85^{\circ}$. Our stratigraphic analysis indicates that the gullies are cut mainly into Miocene and younger formations.

On the basis of the limited data, the floor of Lindenkohl Canyon, although generally more reflective than the surrounding slope, is not as reflective on sidescan images as the floors of Carteret and North Carteret canyons. Chaotic canyon thalweg deposits (Q6) are not identified in the small portion of Lindenkohl Canyon we have mapped. The sidescan images and sub-bottom profiles in Figure 10 do show a hummocky area within the thalweg; however, it is not clear whether this corresponds to an outcrop within the canyon floor, or if it is a mass of allochthonous material derived from upslope or the adjacent walls. 


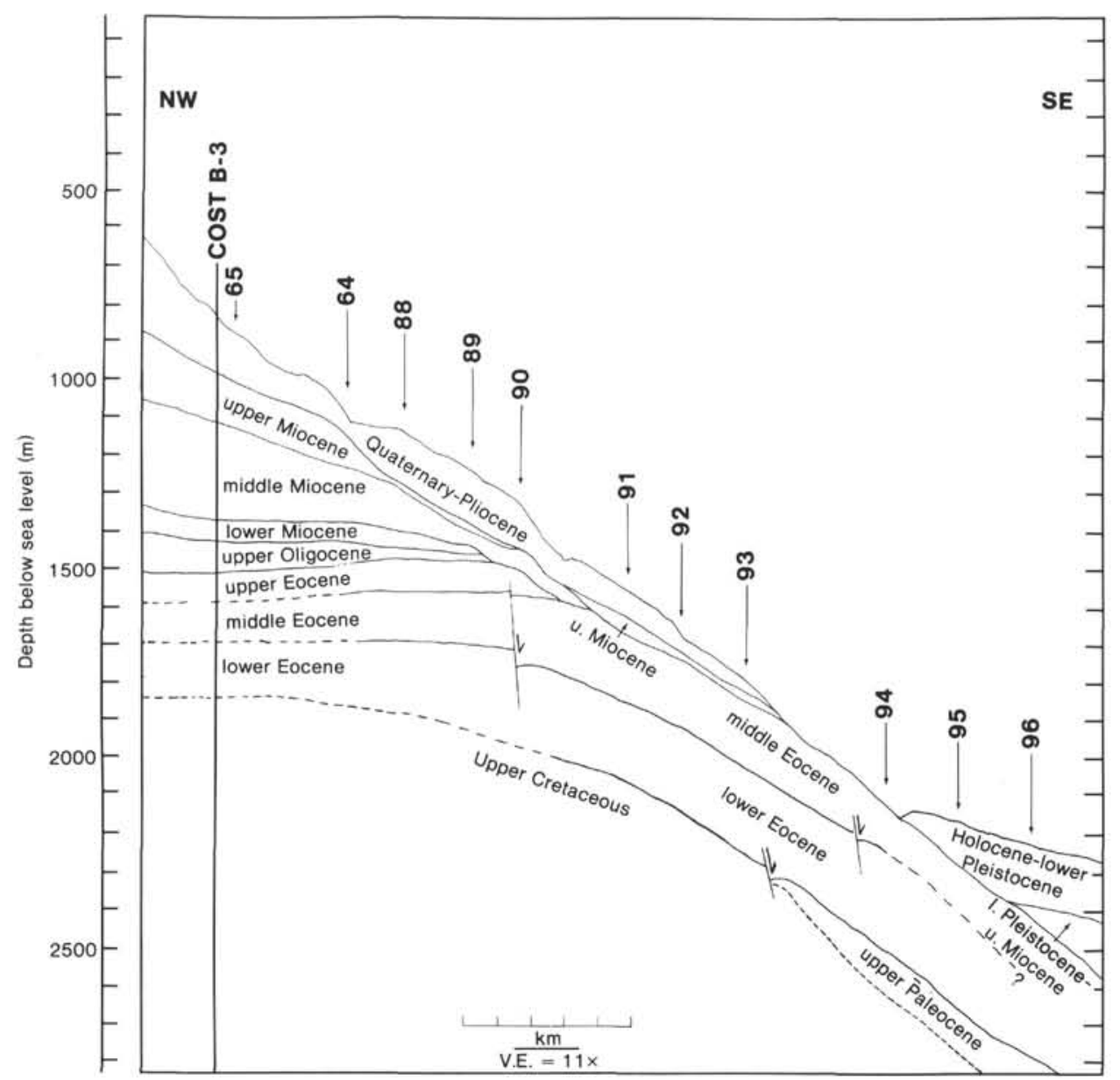

Figure 7. Depth section equivalent to seismic dip Line 77. Seismic velocities, determined from the COST B-3 well (Table 1), were used to construct this figure.

\section{Carteret Canyon}

Carteret Canyon consists of two separate valleys in water depths shallower than $1500 \mathrm{~m}$ : the main valley which extends up to the shelf break and a tributary valley adjacent to the east. The tributary valley is a more direct upslope continuation of the lower slope portion of Carteret Canyon than the main valley which makes a rather sharp bend to the east at the confluence. The cross section of Carteret Canyon and its tributary varies between $V$ shaped and $U$ shaped. In the study area, there is a general trend for the canyons to have broader thalwegs downslope.

Late Pleistocene strata (Q1 and P1) are found in the same two configurations on the walls of Carteret Canyon as they are on all the canyons in the study area. They either thin and drape down canyon walls, or they are abruptly truncated (Fig. 11). Some of these truncations mark the upslope terminations of bedding plane sediment slides (e.g., Summerhayes et al., 1979). These sediment slides generally remove thin (few meters to tens of meters) sections of stratified sediment from broad areas (one half to several square kilometers) of the slope. Their basal glide plane is generally coincident with a sub-bottom reflector of the adjacent undisturbed slope. Their headward bounding scarps are steep and follow serrated to arcuate paths, concave downslope. A steplike or terraced canyon wall results when one or more such slides intersect or are superimposed on one another. In other places along Carteret Canyon, truncation of the Pleistocene strata is along steep declivities and canyon walls are not terraced.

The detailed morphology of Carteret Canyon seaward of the middle continental slope is presented by Farre and Ryan (1985a). In summary, Carteret Canyon can be informally separated into three segments: upper, middle, and lower Carteret Canyon (Fig. 9). At $1700 \mathrm{~m}$, upper Carteret Canyon plummets over a steep, 100-m cliff that has a circular headwall into middle Carteret Canyon. Middle Carteret canyon narrows downslope and nearly dies out at $1950 \mathrm{~m}$ where it feeds into lower Carteret Canyon. Lower Carteret Canyon is one of two flat-floored erosional chutes on the lowermost slope. The floors of these chutes are prominently marked by downslope-trending lineations (light-dark couplets) on side-scan images and hyperbolic reflections on sub-bottom profiles and these lineations are interpreted to be grooves, some few meters deep and wide, cut into the substrate. Some of the grooves originate at headwalls of scarps within the chutes and some are continuous for distances $>2 \mathrm{~km}$. Lower Carteret Canyon is entrenched $15 \mathrm{~m}$ and the adjacent chute to the west almost $40 \mathrm{~m}$ into seaward-dip- 
Table 2. Data summary on surficial deposits.

\begin{tabular}{|c|c|c|c|c|c|}
\hline Unit & $\begin{array}{l}\text { Area }^{\mathrm{a}} \\
(\%)\end{array}$ & Age & $\begin{array}{l}\text { Depth range }{ }^{b} \\
(\mathrm{~m})\end{array}$ & $\begin{array}{l}\text { Thickness } \\
\text { (m) }\end{array}$ & Description \\
\hline Q2 & 33.0 & $\begin{array}{l}\text { m. Eocene- } \\
\text { Quaternary }\end{array}$ & $900-2210$ & $\begin{array}{l}\text { 1-3 } \mathrm{m} \text { drape over } \\
\text { reverberant surface }\end{array}$ & $\begin{array}{l}\text { Hemipelagic drape overlying } \\
\text { reverberant slope strata }\end{array}$ \\
\hline Q1 & 23.9 & Quaternary & $500-2160$ & $<65$ & $\begin{array}{l}\text { Stratified hemipelagites on } \\
\text { slope }\end{array}$ \\
\hline Q3 & 11.4 & Quaternary & $2160-2300$ & $\begin{array}{l}<2 \mathrm{~m} \text { drape over } \\
\text { reverberant surface }\end{array}$ & $\begin{array}{l}\text { Hemipelagites over reverber- } \\
\text { ant rise }\end{array}$ \\
\hline E2 & 11.3 & m. Eocene & $1560-2270$ & $20-120^{\mathrm{c}}$ & Calcareous slope strata \\
\hline P1 & 6.6 & Pleistocene & $400-2150$ & $<65$ & $\begin{array}{l}\text { Stratified hemipelagites on } \\
\text { slope }\end{array}$ \\
\hline E3 & 3.4 & $\mathrm{~m}$. Eocene & $1830-2200$ & $75-120$ & $\begin{array}{l}\text { Grooved calcareous slope } \\
\text { strata }\end{array}$ \\
\hline Q6 & 3.2 & Quaternary & $690-1870$ & $<20$ & $\begin{array}{l}\text { Chaotic canyon thalweg } \\
\text { deposits on slope }\end{array}$ \\
\hline Q4 & 2.3 & Quaternary & $1900-2270$ & $<15$ & $\begin{array}{l}\text { Ponded debris deposits on } \\
\text { slope and rise }\end{array}$ \\
\hline M1 & 1.9 & $\begin{array}{l}\text { 1. Oligocene- } \\
\text { Miocene }\end{array}$ & $1000-1540$ & $\approx 60^{\mathrm{c}}$ & Terrigenous slope deposits \\
\hline E1 & $<1.0$ & $\begin{array}{l}\text { e. Oligocene- } \\
\text { 1. Eocene }\end{array}$ & $1540-1650$ & $\approx 50^{\mathrm{c}}$ & Calcareous slope deposits \\
\hline P2 & $<1.0$ & Plio/Pleistocene & $990-1500$ & $5-20^{c}$ & Terrigenous slope deposits \\
\hline M2 & $<1.0$ & $\begin{array}{l}\text { m. Miocene- } \\
\text { Pleistocene }\end{array}$ & $1380-1560$ & $10-40^{\mathrm{c}}$ & Terrigenous slope deposits \\
\hline Q7 & $<1.0$ & $\begin{array}{l}\text { 1. Pleistocene/ } \\
\text { Holocene }\end{array}$ & $2200-2250$ & NA & $\begin{array}{l}\text { Base of slope depression } \\
\text { with no debris }\end{array}$ \\
\hline Q5 & $<1.0$ & Quaternary & $2160-2215$ & $5-20$ & Hummocky debris on rise \\
\hline $\mathrm{X} 1$ & $<1.0$ & Post $\mathrm{m}$. Eocene & $1995-2140$ & $5-15$ & $\begin{array}{l}\text { Reflective, irregularly } \\
\text { shaped slope deposit }\end{array}$ \\
\hline Q8 & $<1.0$ & $\begin{array}{l}\text { 1. Pleistocene- } \\
\text { Holocene }\end{array}$ & $2200-2205$ & $<5$ & $\begin{array}{l}\text { Base of slope debris beneath } \\
\text { Carteret Canyon }\end{array}$ \\
\hline
\end{tabular}

\footnotetext{
a Total Sea MARC I study area $=530 \mathrm{~km}^{2}$.

b Depth within study area ranges from 400 to $2300 \mathrm{~m}$.

c Sea MARC I's $4.5-\mathrm{kHz}$ sub-bottom profiler cannot penetrate these units. Thicknesses are determined from the U.S.G.S. high-resolution air-gun seismic profiles.
}

ping and planar middle Eocene strata. Both chutes terminate at the slope/rise boundary where a $<40 \mathrm{~m}$ deep, highly reflective oblong depression (Q7) drains parallel to the slope/rise boundary (south) into the valley on the upper rise associated with Lower Slope Canyon A.

At the slope/rise boundary, within the western chute and adjacent to the grooved terrain, lies a small deposit $\left(0.1 \mathrm{~km}^{2}\right)$ of highly-reflective material (Unit Q8). The sub-bottom data show the floors of the chutes to have no sediment drape within them. In contrast, the subbottom data show the open slope adjacent to middle and lower Carteret Canyon to be covered by 1-3 m of Holocene drape.

The floor of the depression on the uppermost rise beneath lower Carteret Canyon is pitted by numerous holes and strewn with small $(5-10 \mathrm{~m})$ acoustic targets with shadows (olistoliths). Downslope of Carteret Canyon and the depression on the rise is a low-relief topographic mound across which radiate several trails, shallow channels, and other subtle textural etchings. At the end of one 4-km-long trail that crosses the gentle $1.5^{\circ}$ incline of the upper continental rise is a reflective object estimated to be several meters in size. We assume that the object is an intact block of indurated sediment that has slid across the upper rise. Two other trails continue without interruption downslope out beyond the limit of the sidescan coverage (Farre and Ryan, 1985a).

\section{Seafloor Visual Observations}

Alvin Dive 1115 (Fig. 4) investigated the oblong baseof-slope depression on the upper rise beneath Carteret
Canyon. The survey track of this dive headed from the depression, upslope along the western wall of lower Carteret Canyon, and crossed over the intervening high into the adjacent western chute, The floor of the base of slope depression is covered by a flocculent gray-brown sediment that was very easily stirred into clouds. Tabular to subrounded blocks of gray-white strata, interpreted to be Eocene in age, are scattered about and are thinly dusted with flocculent sediment or partly buried.

The floor of the chute called lower Carteret Canyon was also visually observed to be dusted with sediment, but the thickness is below that resolvable by our subbottom profiler $(<1 \mathrm{~m})$. The floor of this chute is littered by numerous tabular slabs of gray-white rock as large as $3 \mathrm{~m}$ in diameter sitting on the sediment surface and usually not appreciably covered by sediment. The western wall of the chute showed outcrops of middle Eocene strata varying from bare and massive to fractured sections, partly obscured by patchy sediment. Slabs of the fractured rock litter the adjacent floor.

On the higher divides separating the two chutes, the sediment becomes thin enough to allow intermittent viewing of the underlying Eocene bedrock. Within the floor of the western chute are numerous rounded black boulders in addition to the commonly observed white ones.

\section{North Carteret Canyon}

Unlike Carteret Canyon, North Carteret Canyon is a single valley extending from the upper slope down to $1700 \mathrm{~m}$, where it dies out on the middle Eocene outcrop. The most distinctive characteristic of North Carteret Can- 


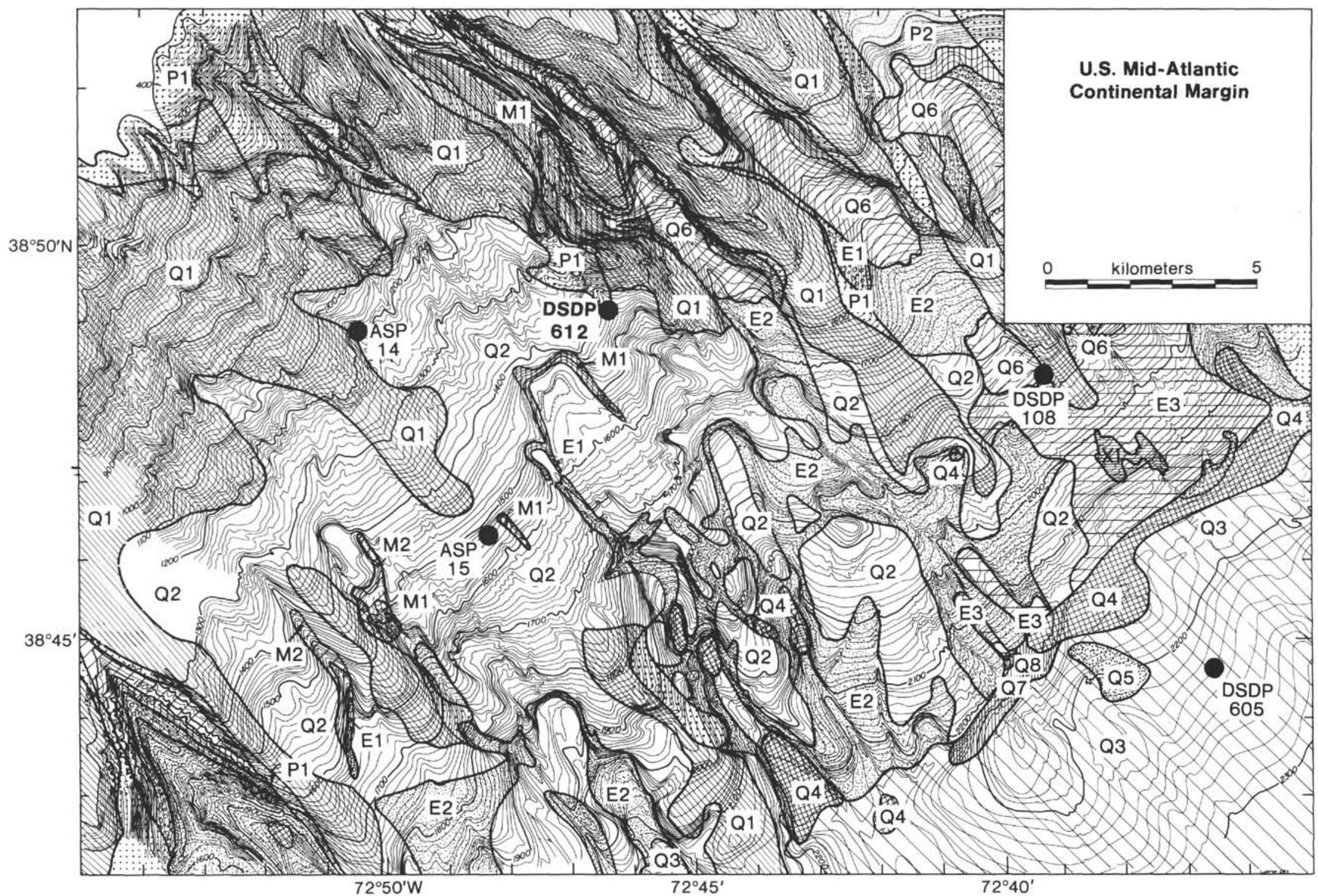

Figure 8. Geology of the surficial deposits in the study area. For description of the unit, see Table 2. 


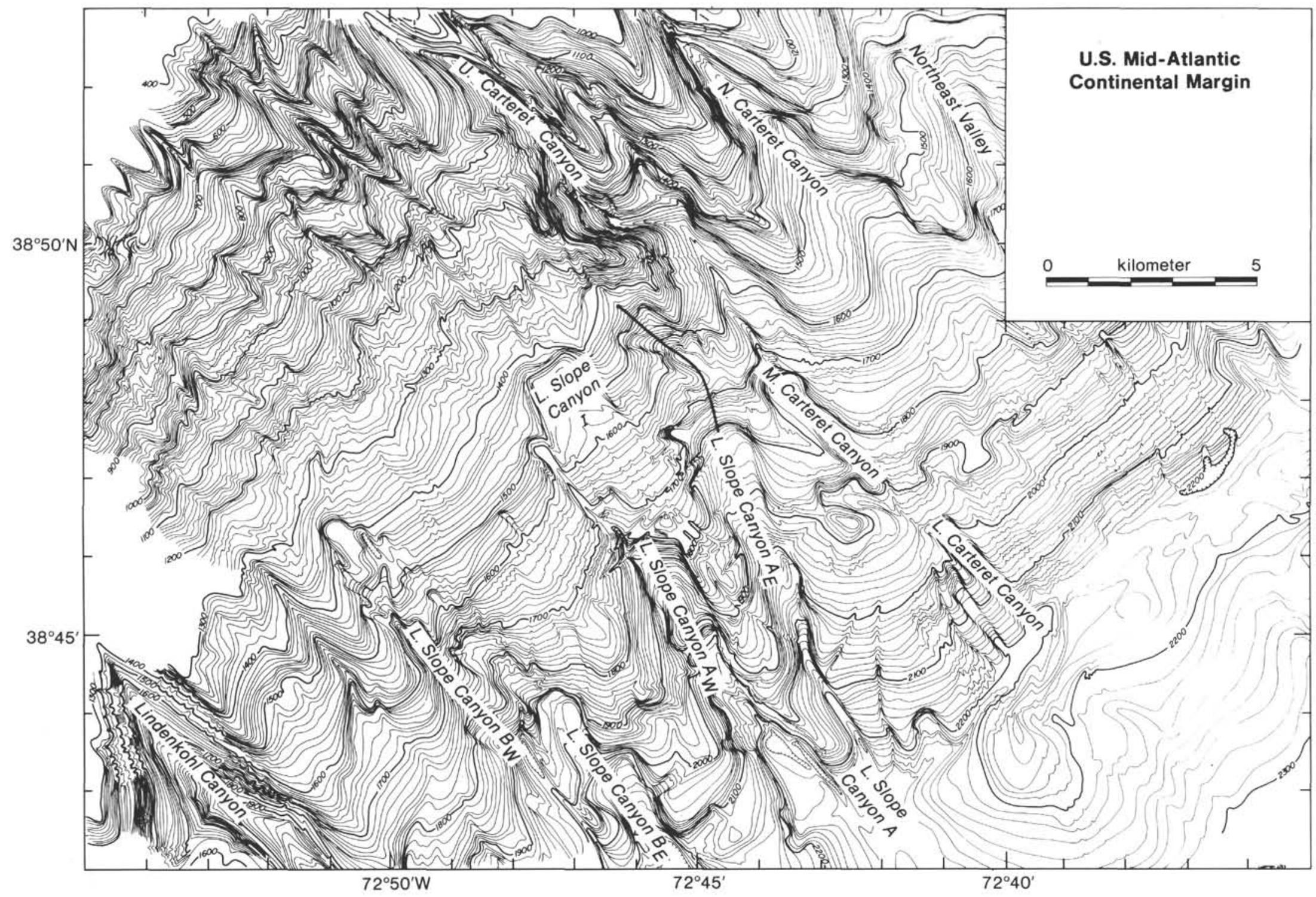

Figure 9. Map of the Sea MARC I study area showing names of the submarine and lower slope canyons. The line extending upslope from Lower Slope Canyon $\mathrm{A}_{\mathrm{E}}$ is the inferred buried continuation of the canyon that was sampled at Site 612 . 
SW
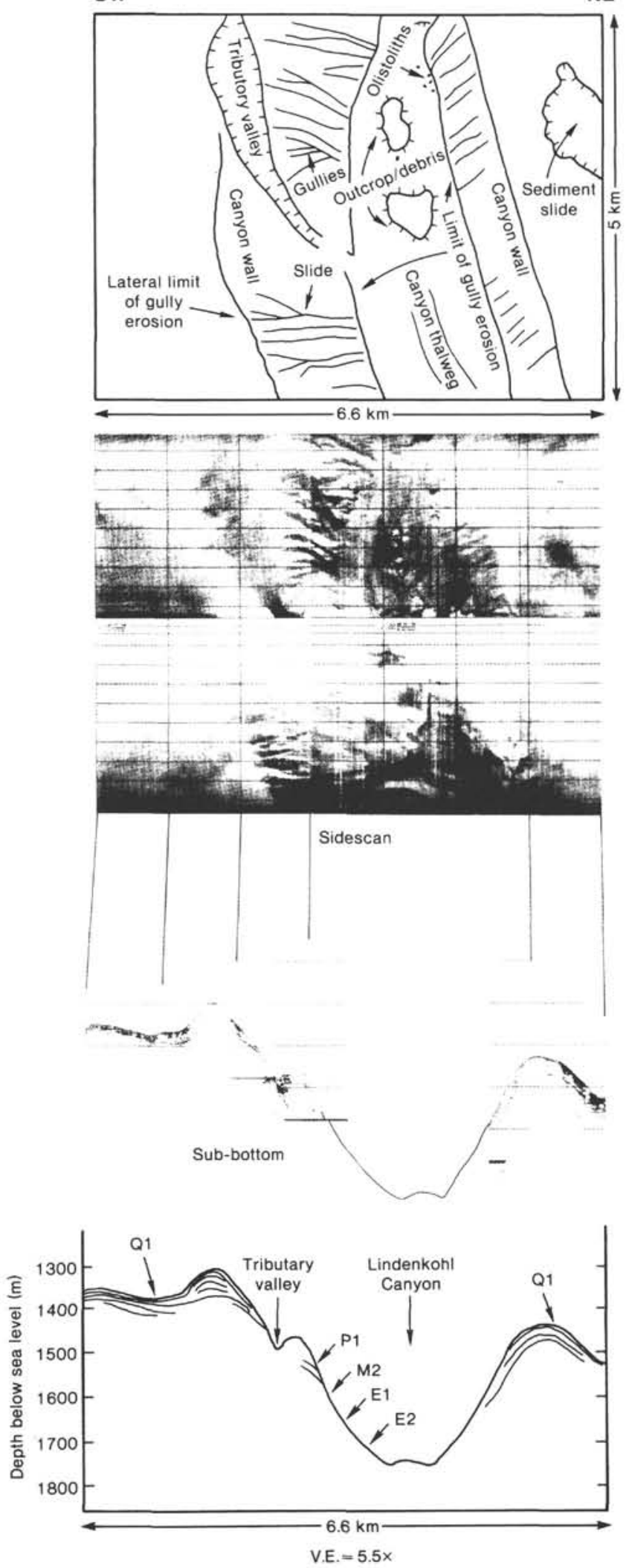

Figure 10. Sea MARC I sidescan/sub-bottom pair: Lindenkohl Canyon on the middle and lower continental slope. Well-developed canyon-wall gullies are confined to unconsolidated, terrigenous deposits of Miocene and younger age. For location of this and other figures within the study area, see Figure 6 . yon is its highly reflective thalweg which is generally marked by downslope-trending lineations on sidescan images (Fig. 11). If the lineations have relief, then that relief is below the resolution of our sub-bottom profiler. A $<20 \mathrm{~m}$ thick, reverberent, semitransparent, nonstratified thalweg deposit $\left(\mathrm{Q}_{6}\right)$ is present in the canyon upslope of $1600 \mathrm{~m}$ and another patch occurs at $1800 \mathrm{~m}$ near DSDP Site 108 (Fig. 8). Beneath this patch on the lower slope is an area of grooved Eocene strata that continues down to the slope/rise boundary.

\section{Upper and Middle Continental Slope}

Quaternary sediments, except in the thalwegs of the three main canyons, cover the upper and middle continental slope in the study area. Much of the open slope (away from the three canyons) and the intercanyon spurs are draped by as much as $50 \mathrm{~m}$ of acoustically stratified sediment (Q1 and P1). The thickest, least disrupted, and apparently most complete sections occur only on the intercanyon spurs. This $50 \mathrm{~m}$ is the maximum penetration achieved with our deep-towed sub-bottom profiler. In places where the uppermost portion of the stratified unit is missing, penetration is correspondingly reduced, implying that the $4.5-\mathrm{kHz}$ acoustic energy dissipates everywhere at the same stratigraphic level.

\section{Open Slope}

On the open upper and middle slope, west of the canyons, the layering within Q1 and P1 drape an underlying erosional surface. Present-day seafloor topography, however, does not in general parallel this underlying surface, but incises the stratification within Q1 and P1. Where present, Holocene drape covers the upper erosional surface, resulting in numerous angular unconformities. Over broad areas of the open middle slope, erosion has cut deeply into the subsurface. Here, we distinguished the drape and its reflective base (all the stratified sediment missing) as Unit Q2 (Fig. 12). Upslope of Q2, significant thickness of subsurface stratification $(\mathrm{Q} 1$ and P1) reappear. ASP-14 penetrated the non-stratified Unit Q2 and sub-bottom data from adjacent lines (closer than $500 \mathrm{~m}$ ) show only a reverberant echo beneath a thin transparent drape. The biostratigraphic data released from ASP-14 are not complete, but the topmost portion of the section is deemed Pleistocene (Poag, 1985a). These drilling results, at ASP-14, indicate that Pleistocene sediments occur on the middle slope within Q2, but the sub-bottom profiles indicate that their acoustic character is different and they are older than those found in Units Q1 and P1.

Sidescan reflectivity on the open middle slope is controlled mostly by variations in the thickness of the 1$3 \mathrm{~m}$ of Holocene drape present over the area. The sidescan images reveal a subtle downslope-trending fabric from low-relief gullies cut into the underlying erosion surface (Figs. 12 and 13).

\section{Seafloor Visual Observations}

Photographs from the middle slope, away from the canyons, invariably show greenish-brown sediment work- 

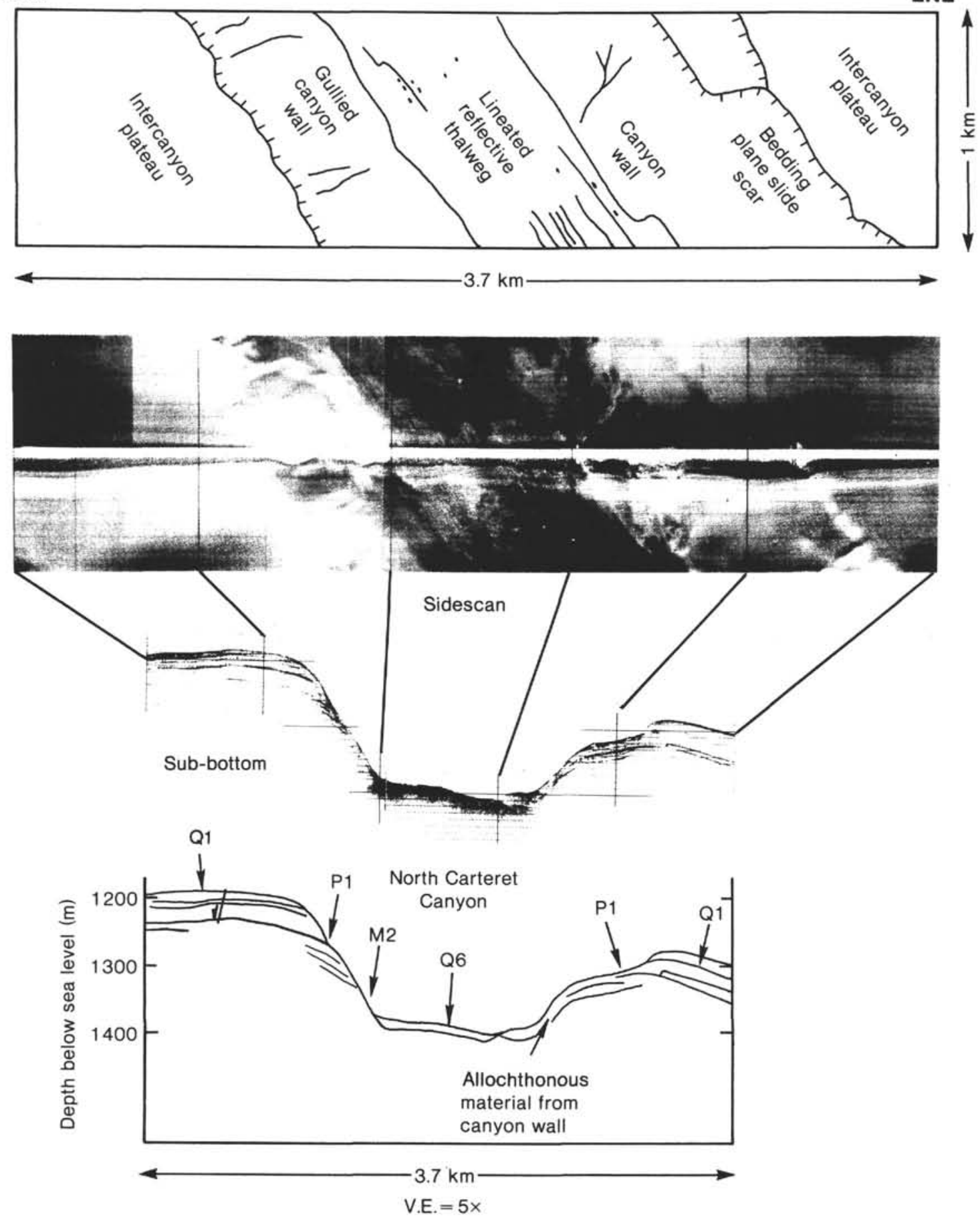

Figure 11. Sea MARC I sidescan/sub-bottom pair: Middle continental slope, canyon wall, and thalweg morphology. Crossing of North Carteret Canyon showing bedding plane sediment slide scar on canyon wall, lineated, reflective thalweg deposit, and canyon wall gullies.

ed in varying degrees into mounds and holes by benthic organisms. Trails, tracks, and living creatures are abundant.

\section{Lower Continental Slope}

The lower continental slope in the study area can easily be separated into two morphological provinces. One, west of lower Carteret Canyon, is incised by two major lower slope canyon systems and several smaller ones (Fig. 9) which extend upslope no further than the 1450-m isobath. The other province, east of Carteret Canyon, is undissected by canyons. Much of this canyonless province, however, is incised by predominantly downslopetrending grooves cut into the seaward-dipping middle Eocene substrate. 

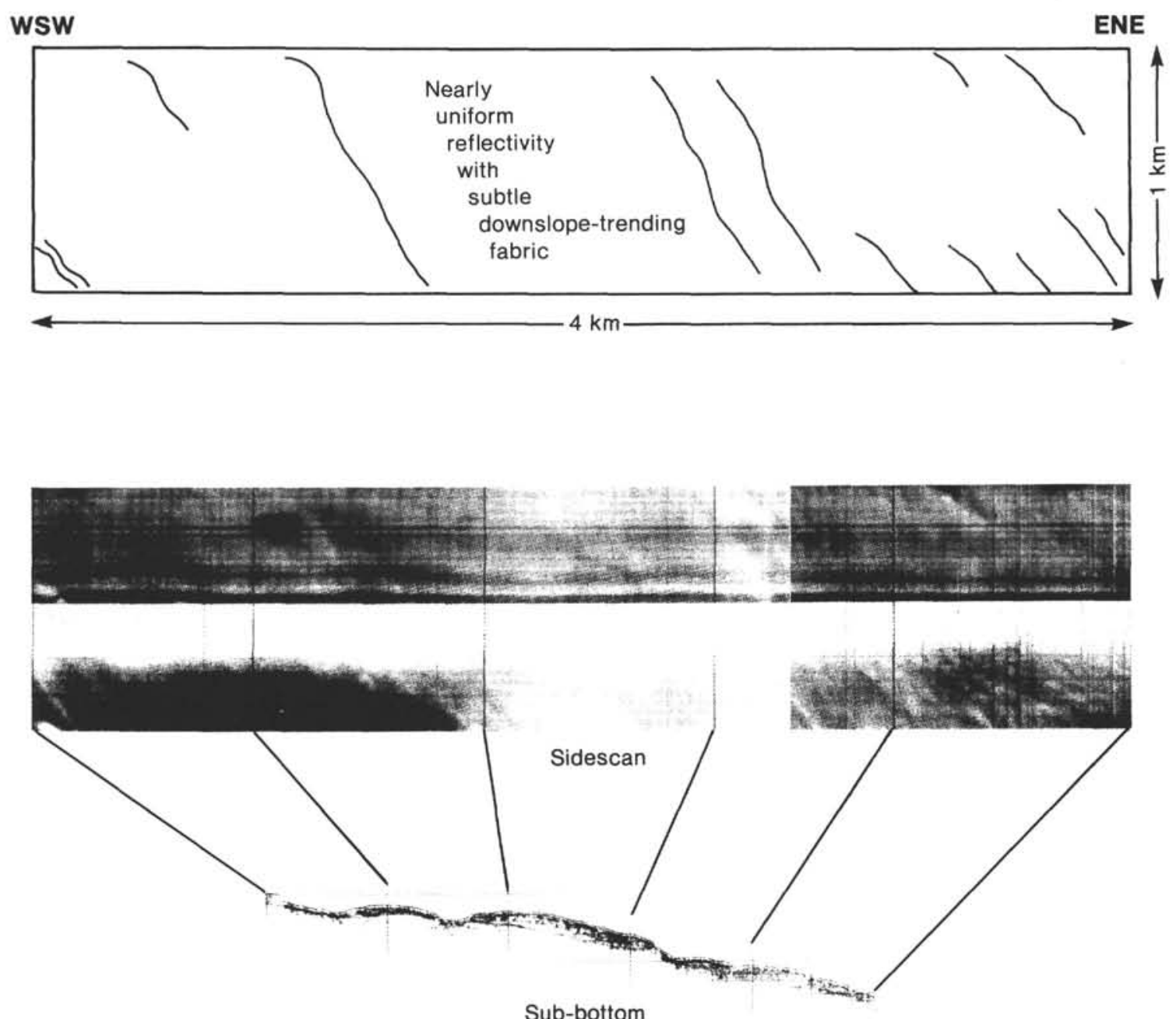

Sub-bottom

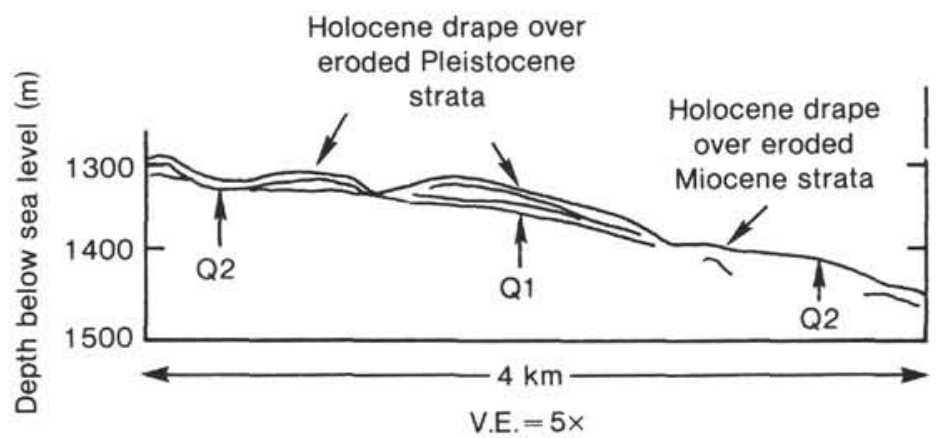

Figure 12. Middle continental slope, Holocene drape over Pleistocene-Miocene strata. Sea MARC I sidescan/sub-bottom pair: Nearly uniform sidescan reflectivity due to a 2- to 5-m-thick Holocene drape. The erosional truncation and dissection of the underlying stratified deposits, and the subtle downslope-directed fabric, are evidence for late Pleistocene downslope-directed current erosion.

\section{Lower Slope Canyons}

The two major canyon systems (A and B Fig. 9) in the province west of lower Carteret Canyon show the same general morphology. They have steep (in places vertical) side and head walls which cut deeply into Eocene strata and have wide $(0.3-2 \mathrm{~km})$, nearly flat floors. Their steep bounding walls may be single cliffs, or they may be terraced with steep segments offset by gently seawarddipping planar sections interpreted to coincide with bedding within the Eocene section (Fig. 14). The deepest part of the canyon cross section is commonly adjacent to the walls. In these instances, the center of the floor is 10-30 m higher than the base of the walls. The central 

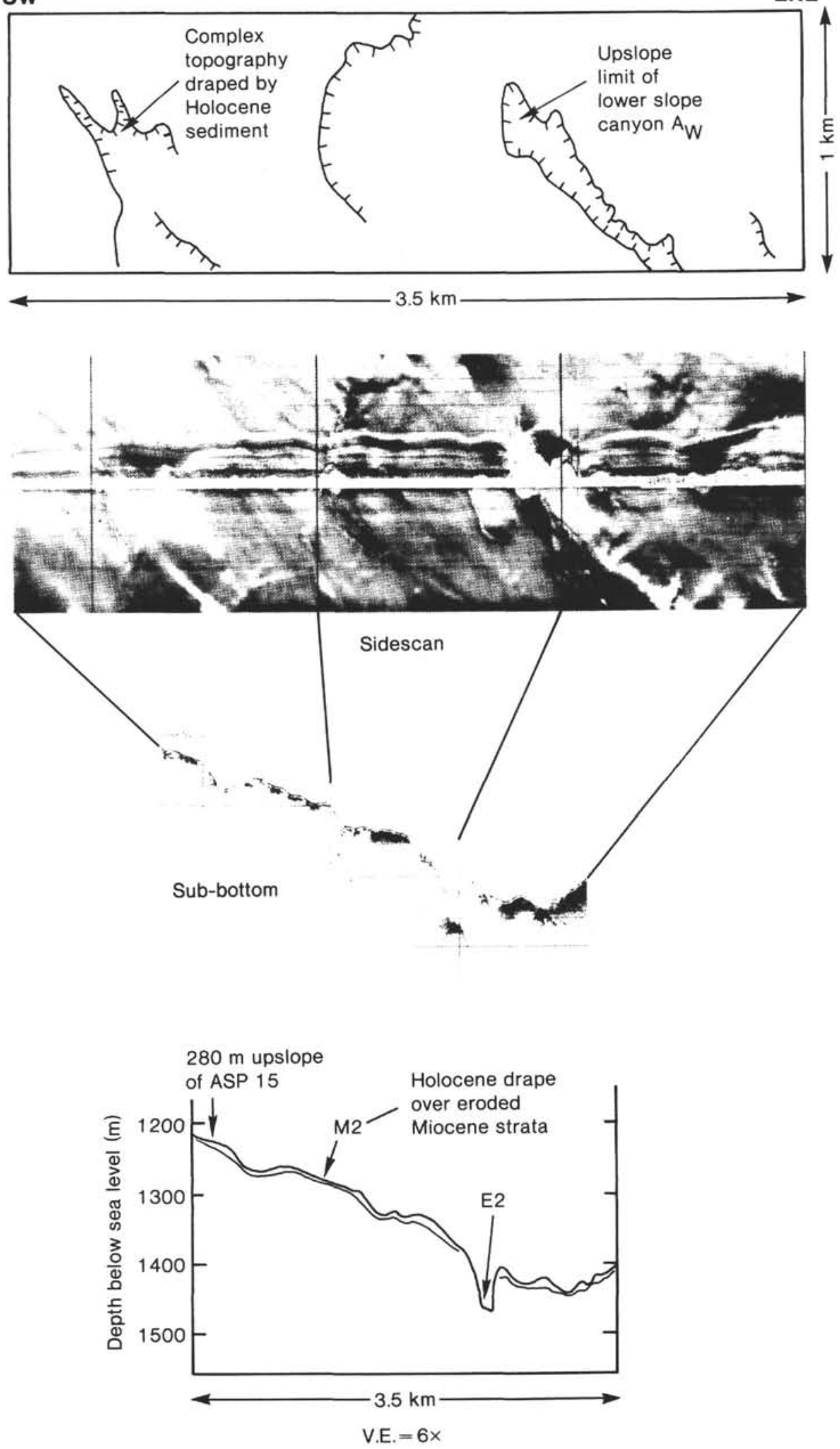

Figure 13. Sea MARC I sidescan-sub-bottom pair: Middle continental slope. Holocene drape over nonstratified Miocene strata, calibrated at Site ASP-15. 

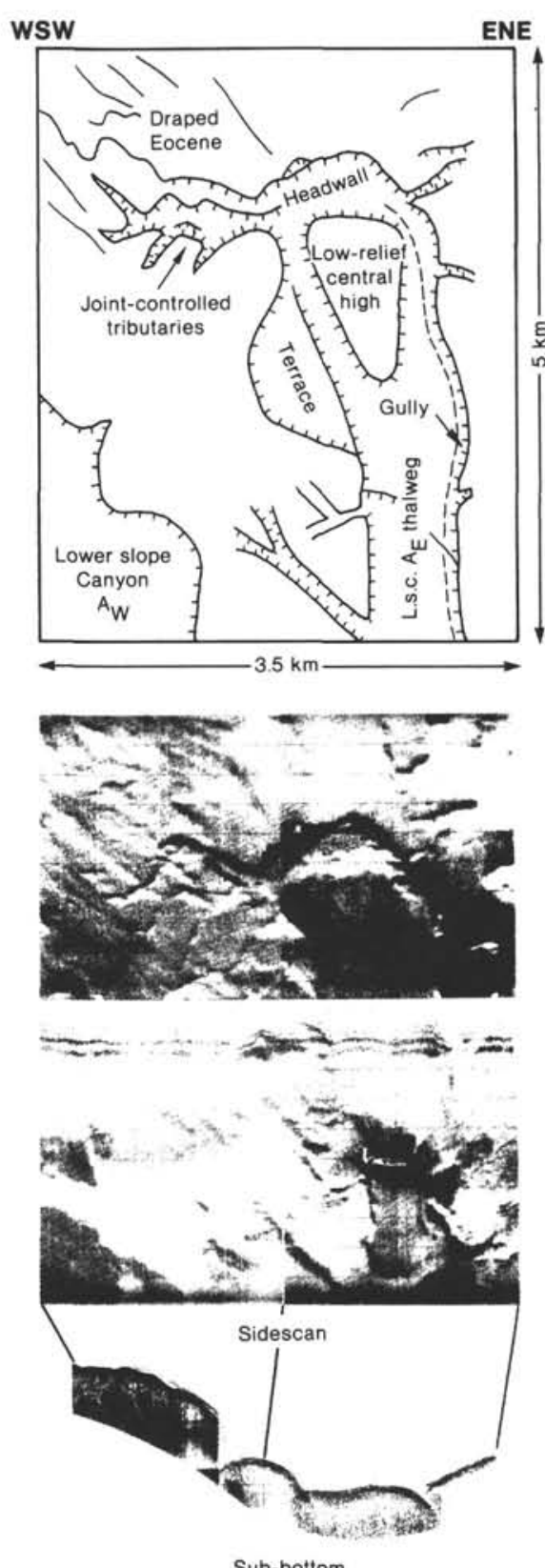

Sub-bottom

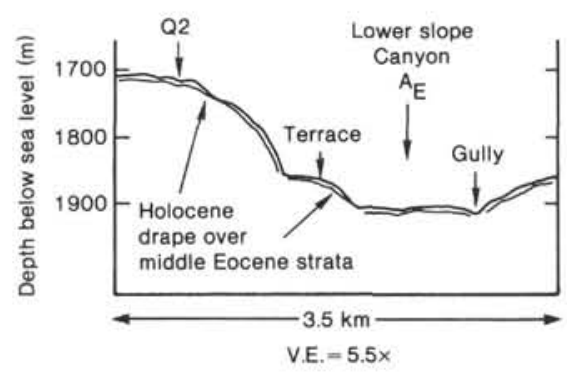

Figure 14. Sea MARC I sidescan/sub-bottom pair: Upper reaches of Lower Slope Canyon $\mathrm{A}_{\mathrm{E}}$. Joint control on canyon morphology is suggested in the sidescan image where angular headwall and tributary valleys parallel the prominent $\mathrm{NE} / \mathrm{SW}, \mathrm{NW} / \mathrm{SE}$ joint trends. An important question is whether the angular tributary network is primarily a result of removal of material through gravitational mass failure along structural weakness, or whether joints were open into a tributary network by corrosive ground waters or contour currents. high generally continues downslope, but in Lower Slope Canyon I (Fig. 15) the central high is an isolated, 30-mhigh, closed contour mound. Downslope, within the axis of lower slope canyons, gently seaward-dipping sections are commonly offset by steep arcuate to angular cliffs (Fig. 16). There are consistent NE/SW and NW/ SE orientations to angular headwalls in such cliffs. Nearly orthogonal intersections dominate.

The two major lower slope canyon systems branch upslope. One such branch of Lower Slope Canyon B extends upslope over $6 \mathrm{~km}$. In places, side chutes feed the lower slope canyons. On sidescan images, they appear as sharply defined, linear features that resemble excavated cracks in the consolidated Eocene strata (Fig. 14). The chutes parallel the predominant NE-SW, NW-SE structural fabric present within the Eocene section.

Patches of Quaternary sediment (Q1, P1) occur locally on topographic highs along the margins of the canyons on the lower slope. In places, the uppermost skin of the Quaternary section is missing where it has slid into the canyon.

Both lower slope canyon systems incise the middle Eocene section nearly down to the middle/lower Eocene boundary (Fig. 17). The relief of the lower slope canyons is as great as $175 \mathrm{~m}$ on the lower slope, but presentday relief abruptly lessens seaward of the slope-rise boundary (Fig. 18). The canyons continue as topographic features on the middle Eocene surface beneath the onlapping continental rise, but the top-of-wall to thalweg relief decreases to $<50 \mathrm{~m}$. These buried canyons continue to decrease in cross-sectional size and vertical relief in the seaward direction for $\sim 4 \mathrm{~km}$ beneath the upper rise to strike Line 96, where no expression of the canyons can be identified in the subsurface.

\section{Seafloor Visual Observations}

Alvin Dives 1112 and 1113 and L-DGO camera Tows 5,6 , and 13 cross the lower slope canyons (Fig. 4). Photographs from within the canyons show the physical integrity of the exposed grey-white Eocene strata to vary widely. Most canyon wall outcrops are nearly vertical, with massive exposures offset by nearly horizontal benches giving an overall stepped or terraced morphology. Some of the massive outcrops appear polished while others show a small scale $(2-4 \mathrm{~cm})$ pitted surface. Many massive vertical faces show horizontal linear indentations only 2-5 cm deep and up to tens of centimeters long. One cliff face at $1990 \mathrm{~m}$ within Lower Slope Canyon A shows a series of noncontinuous, vertical furrows approx. $2-5 \mathrm{~cm}$ deep cutting the canyon's west wall (fig. 3E of Robb, 1984). Horizontal check marks are also visible in this outcrop.

Other canyon wall cliffs show highly jointed middle Eocene strata. Angular rock slabs, clearly detached from adjacent outcrop, generally have bedding planes and vertical joints as bounding surfaces. Some valley walls are talus slopes littered by angular pieces of chalky strata and dusted by sediment. Some cliffs posses an orthogonal, nearly vertical set of joints which apparently align with the NW-SE, NE-SW structural trends identified in the sidescan images. 

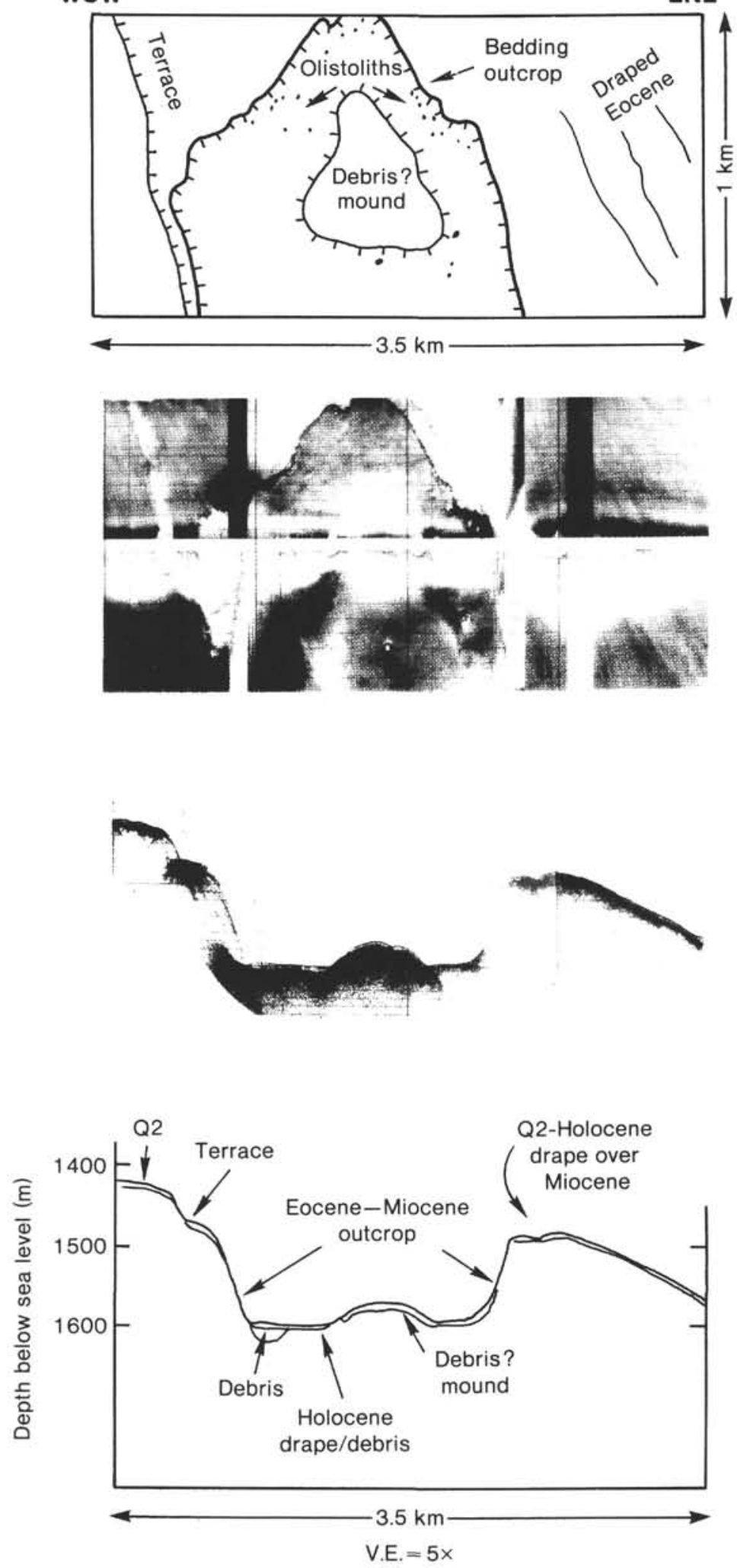

Figure 15. Sea MARC I sidescan/sub-bottom pair: Headwall of Lower Slope Canyon I. Bedding outcrops and headwalls that meet at nearly orthogonal angles indicate structural control on lower slope canyon morphology. Blocks displaced from the steep wall litter the canyon floor. The topographic mound in the canyon floor may either be an erosional remnant or a debris pile deposited in mass failure from the canyon headwall. 

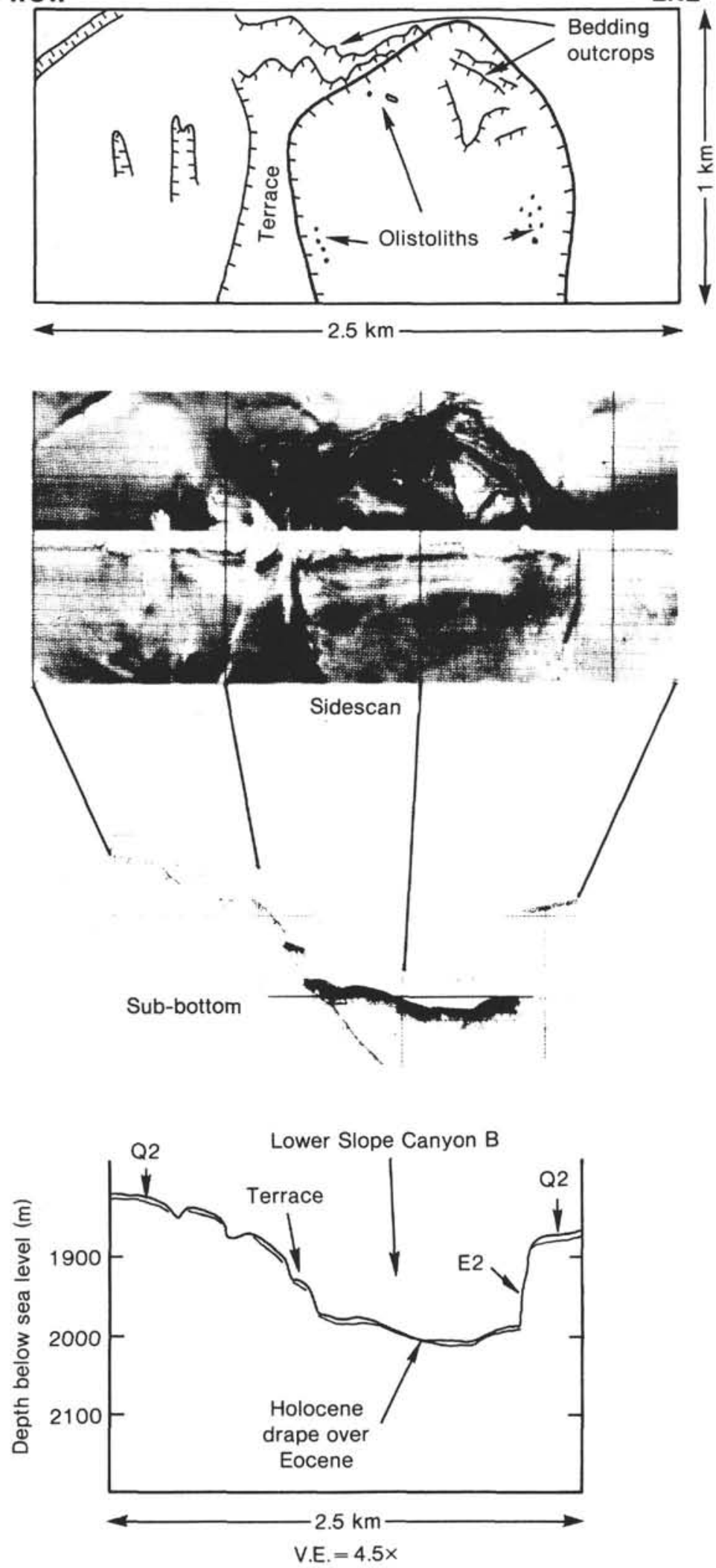

Figure 16. Sea MARC I sidescan/sub-bottom pair: middle Eocene outcrop associated with Lower Slope Canyon B. The angular, nearly orthogonal headwall intersection and the numerous bedding outcrops imply that lower slope morphology is controlled by a NE/SW, NW/SE joint set intersecting with seaward dipping bedding planes. 

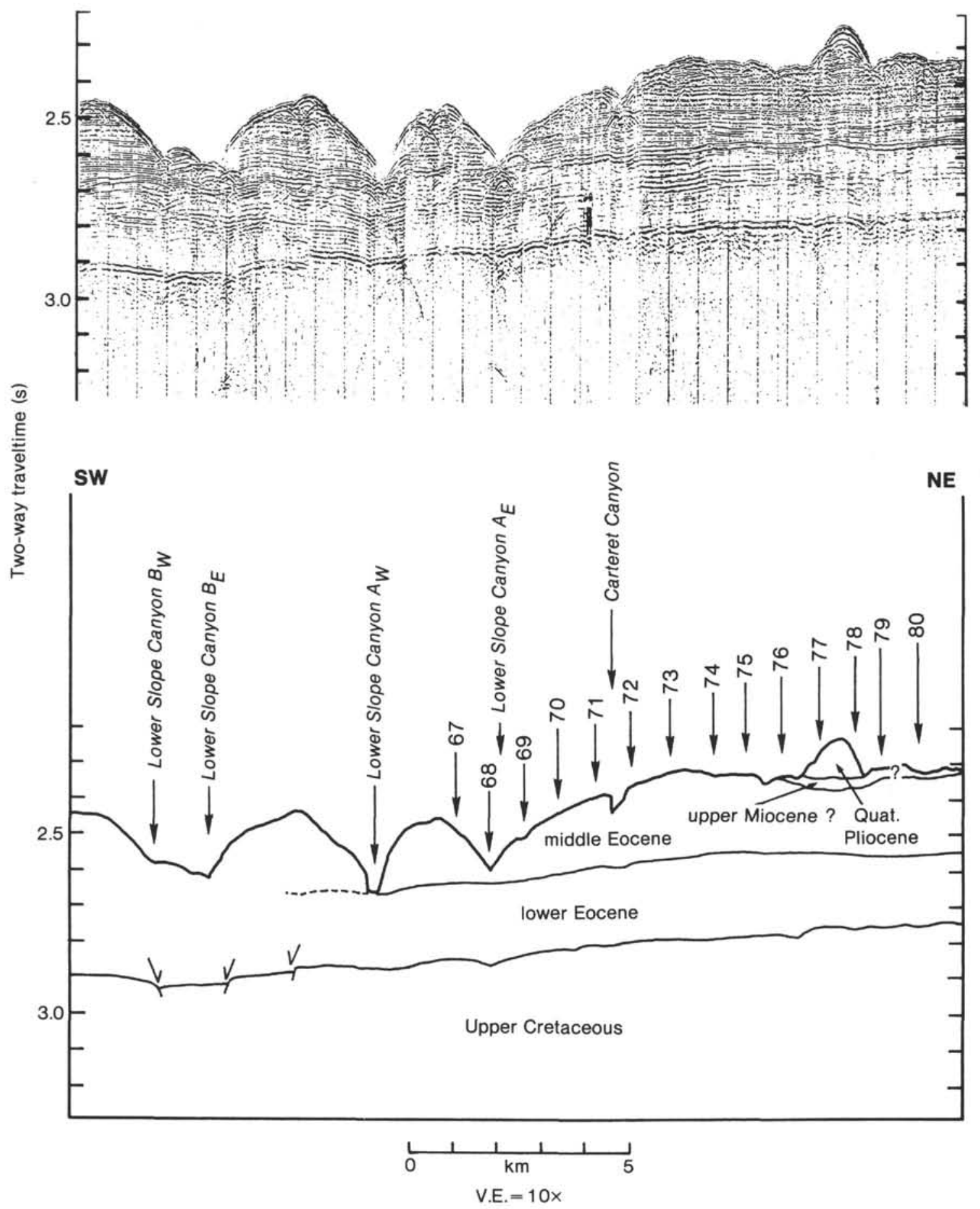

Figure 17. Seismic strike Line 92 and interpretation of the lower continental slope showing the deeply incised nature of Lower Slope Canyons A and B.

Lower slope canyon floors are generally sediment covered and are occasionally littered by slabs of Eocene talus. Instrument tracks made in the sediment by an Edo Western deep-tow sidescan-sonar system in 1981 (ECHO Project, Phase II) were visible from Alvin in 1982 with little sign of degradation or infill.

\section{Grooved Substrates on the Lower Continental Slope}

In the canyonless province, east of lower Carteret Canyon, there is a broad area that is marked by downslope- trending lineations on sidescan images (similar to those described beneath Carteret Canyon). The sub-bottom profiles display a series of hyperbolic echos tangent to horizons only a few meters below the seafloor (Fig. 19). The interpretation of the lineations as grooves is confirmed by observations from DSRV Alvin (Rawson and Ryan, 1978; Robb et al., 1983).

Most grooves are continuous over long distances $(>1 \mathrm{~km})$ and are somewhat regularly spaced $(15-30 \mathrm{~m}$ apart). They occasionally display upslope and downslope 


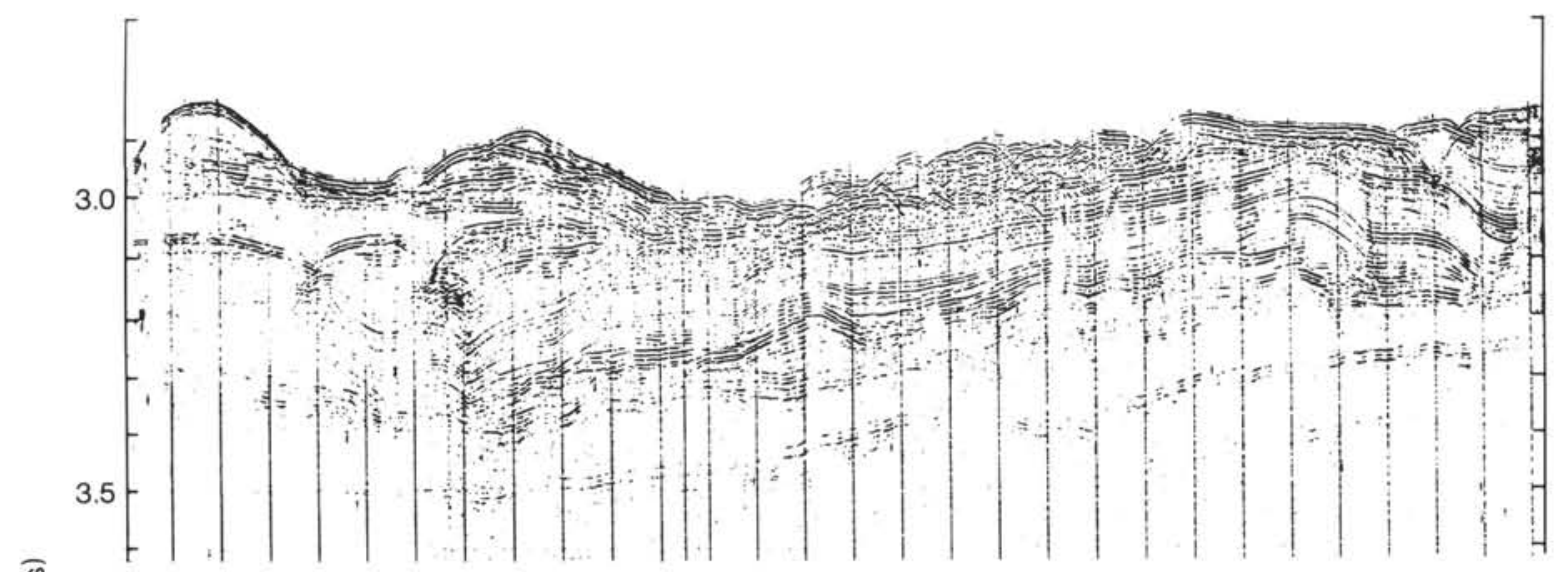

क्ञ

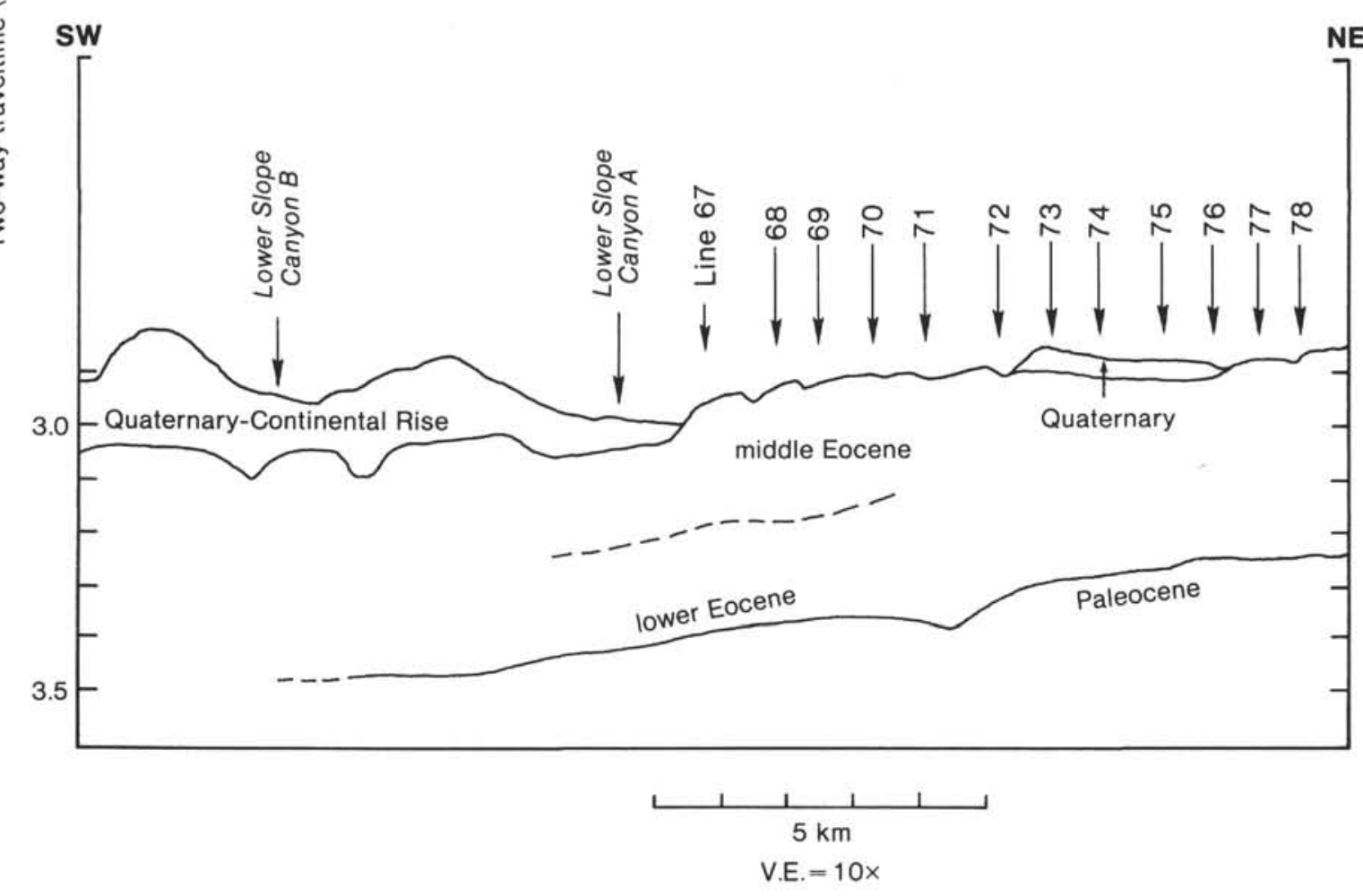

Figure 18. Seismic strike Line 94 and interpretation along the slope/rise boundary. Rise valleys are continuous with the lower slope canyons, indicating that currents passed through or originated within the lower slope canyons during the late Pleistocene. The reduced relief of the canyons (compared with Fig. 16) on the buried middle Eocene surface implies significant canyon incision synchronous with continental rise onlap.

branching. While the vast majority of grooves trend directly downslope, some follow curved to oblique paths across the slope (Fig. 20) and sometimes collect adjacent grooves into a single path (Fig. 21).

Most of the grooves we have imaged fade and disappear upslope beneath canyon thalweg deposits (Q6). Some of the grooves in the chutes beneath Carteret Canyon appear to begin at headland scarps, but such a relation cannot be demonstrated for the majority of grooves in the study area. Grooves are clearly truncated downslope at the headwalls of erosional scars within the Eocene section.

It is difficult to determine the cross-sectional shape and size of the grooves from our remotely sensed data, but observers, diving in grooves on the lower slope be- neath Berkeley Canyon ( $5 \mathrm{~km}$ NE of our study area), described walls of whitish rock commonly steeper than 45 degrees and flat floors 4-13 m deep and 3-5 m wide with a thin, featureless fine-grain sediment cover (Robb et al., 1983). These dimensions are consistent with our acoustic data for the largest grooves (these with the best developed hyperbolic echos in sub-bottom profile). Grooves in the study area with less distinct hyperbolae are probably smaller than those visited by Alvin.

\section{Continental Rise}

The subtle topography of the continental rise contrasts sharply with the deeply eroded, clifflike topography of the continental slope. 
WSW

ENE

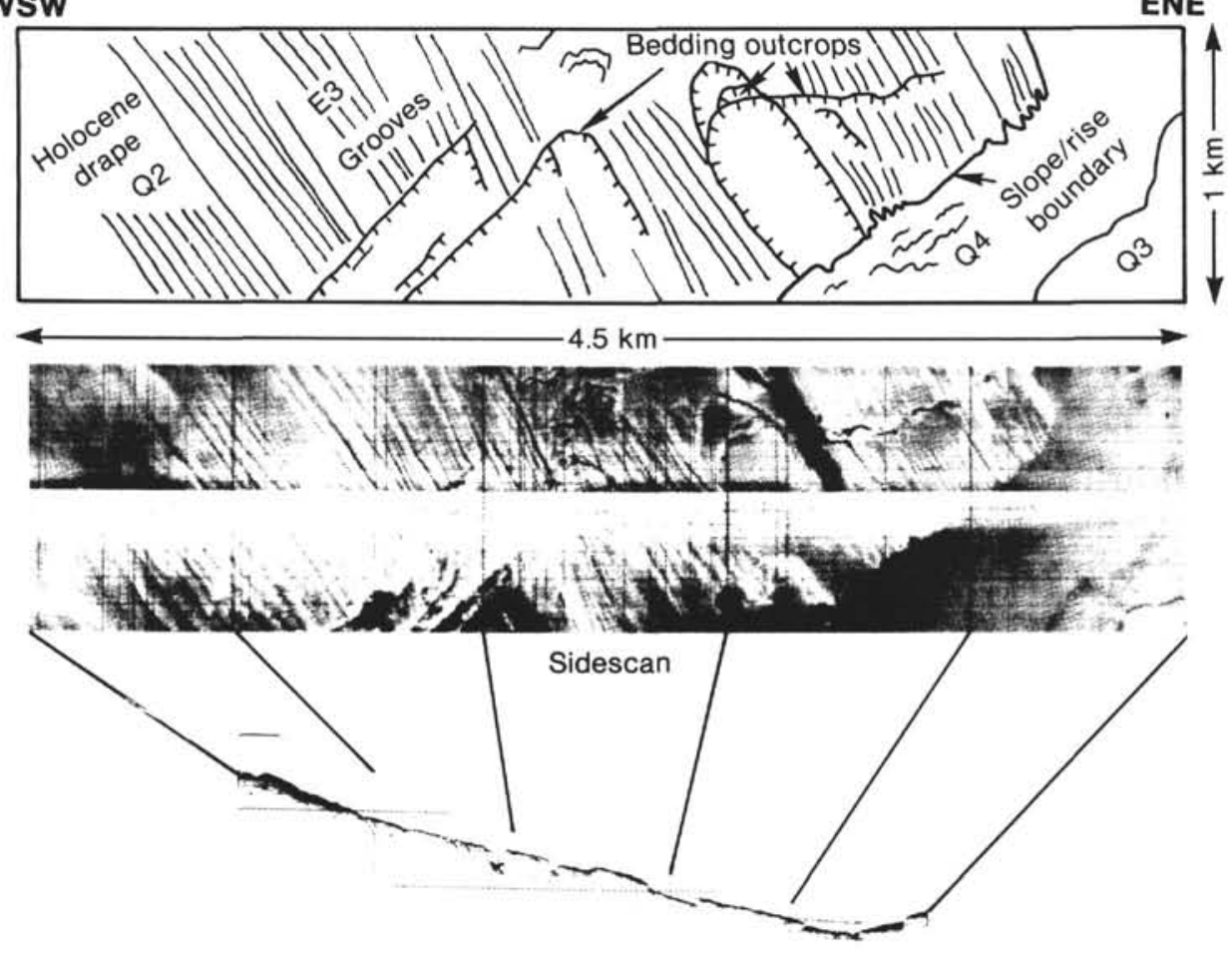

Sub-bottom

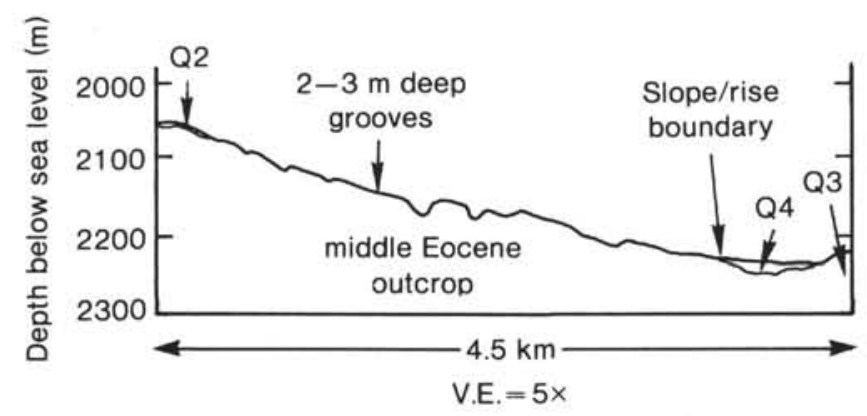

Figure 19. Sea MARC I sidescan/sub-bottom pair: Grooved middle Eocene outcrop on the lower continental slope. Note that these grooves terminate the site of the onlapping continental rise debris unit (Q4), indicating that these grooves are older than Unit Q4.

At the continental slope/rise boundary, the seafloor gradient abruptly decreases from 4.5 to $1.5^{\circ}$. Precisely at this boundary lies an acoustically transparent, reliefsmothering deposit with a nearly horizontal upper surface. (Figs. 8 and 20). This smoothing unit (Q4) is $\sim 900 \mathrm{~m}$ wide, $<15 \mathrm{~m}$ deep, and extends $>6.5 \mathrm{~km} \mathrm{NE}$ along the slope/rise boundary out of the study area. Q4 thins out at its SW margin within the oblong depression (Q7).

The oblong topographic depression beneath Carteret Canyon on the upper rise drains towards the SE into the continuation of Lower Slope Canyon A. Most of the depression is devoid of identifiable ponded deposits, although sidescan images indicate that is is pitted by numerous holes and strewn with olistoliths.

The channel on the rise associated with Lower Slope Canyon A is marked by downslope-trending lineations and is littered by olistoliths. Shadow lengths on sidescan images indicate that the largest olistoliths rise above the seafloor as high as $7 \mathrm{~m}$.
Just seaward of the NE end of the oblong depression is a $1.5 \mathrm{~km}^{2}, 20$-m-thick deposit (Q5) that lacks internal stratification and has a hummocky surface in sub-bottom profile. The sidescan images show this inferred debris unit to be marked by downslope-trending lineations. At its downslope terminus, olistoliths again litter the seafloor (Fig. 22).

The least common morphology seen on sidescan images is a uniformly reflective, featureless continental rise. The most common features are downslope-trending tracks and trails, with relief below the resolution of the subbottom profiler. The second most common terrain is a hummocky and pitted rise surface.

Looking slightly deeper into the sedimentary section, the U.S.G.S. high-resolution seismic profiles show that the structure of the uppermost continental rise at the slope/rise boundary varies along strike (Fig. 23). In the west, (seismic Lines 67 through 71 ), the previously discussed topographic depression (Q7) trends parallel to the slope/rise boundary. There is an $\sim 20$-m-high topograph- 

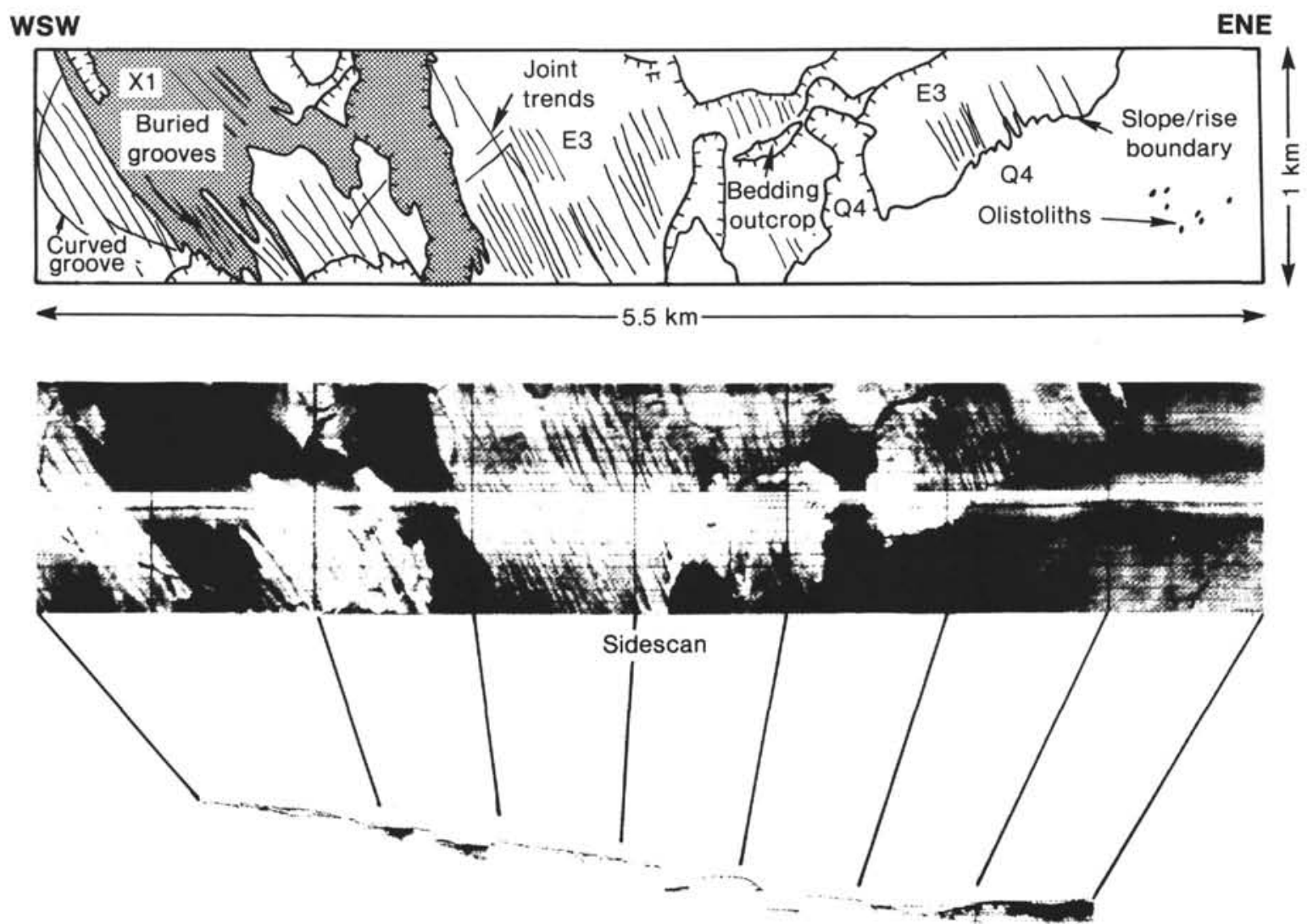

Sub-bottom

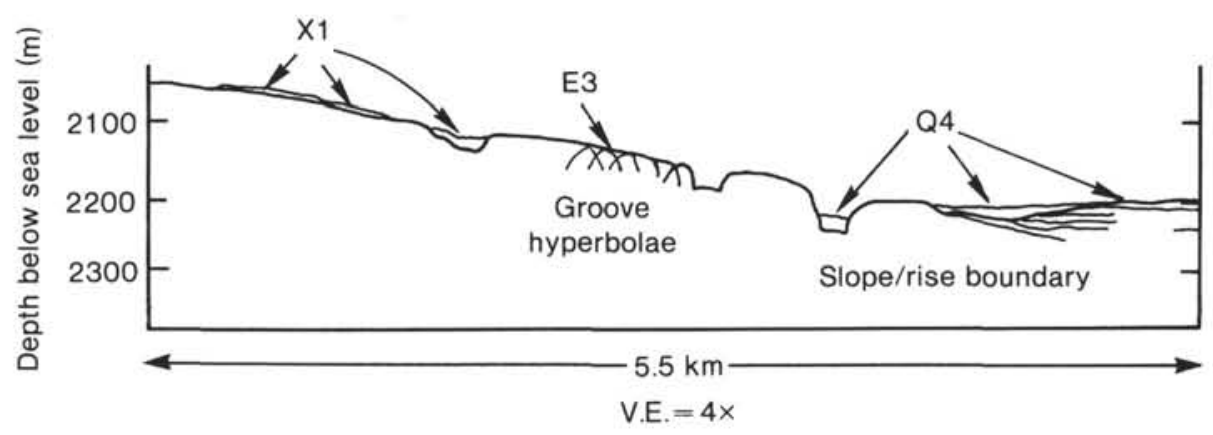

Figure 20. Sea MARC I sidescan/sub-bottom pair: Ponded debris (Q4) and stratified continental rise deposits (Q3) onlapping grooved middle Eocene outcrop of the lower continental slope. The irregularly shaped, highly reflective unit (X1) overlies and partly obscures grooves present in the substrate. Note the curved groove and other cross-cutting relationships in the western portion of the sidescan image.

ic ridge that rims this depression on its seaward side. Dip Line 72 shows this depression and its associated ridge, but a 10 -m-thick horizontally bedded unit partially fills the depression floor. The depression is completely filled at dip Lines 73 and 74 with $\sim 70 \mathrm{~m}$ of stratified sediment. Dip Lines 75 and 76 show no base-of-slope depression either at the surface or buried. Dip Lines 77 through 80 and 97 show a second surficial 30-m-deep depression with a less pronounced bounding ridge. All these lines show that the depression is empty except dip Line 78 , where $\sim 10 \mathrm{~m}$ of stratified sediment is indicated, Dip Line 98 shows no depression. A third baseof-slope depression begins at dip Line 99 and extends to dip Line 106. Its depth deepens from $35 \mathrm{~m}$ at Line 99 to $70 \mathrm{~m}$ at Line 105 and shallows back to $35 \mathrm{~m}$ at Line 106 .
This depression is empty except at Lines 99 and 106, where it is partially filled by $\sim 15 \mathrm{~m}$ of stratified sediment. In the subsurface, buried depressions are identified on dip Lines $73,74,79,80$, and 105 at former positions of the slope/rise boundary.

\section{DISCUSSION}

\section{Modern Seafloor Morphology, Structure, and Processes}

\section{Submarine Canyons and Downslope-Directed Erosion}

The stratigraphic data indicate that there are at least two separate acoustic units of Pleistocene age in the study area. Acoustic Units Q1 and P1 (upper Pleistocene-Hol- 
SW

NE
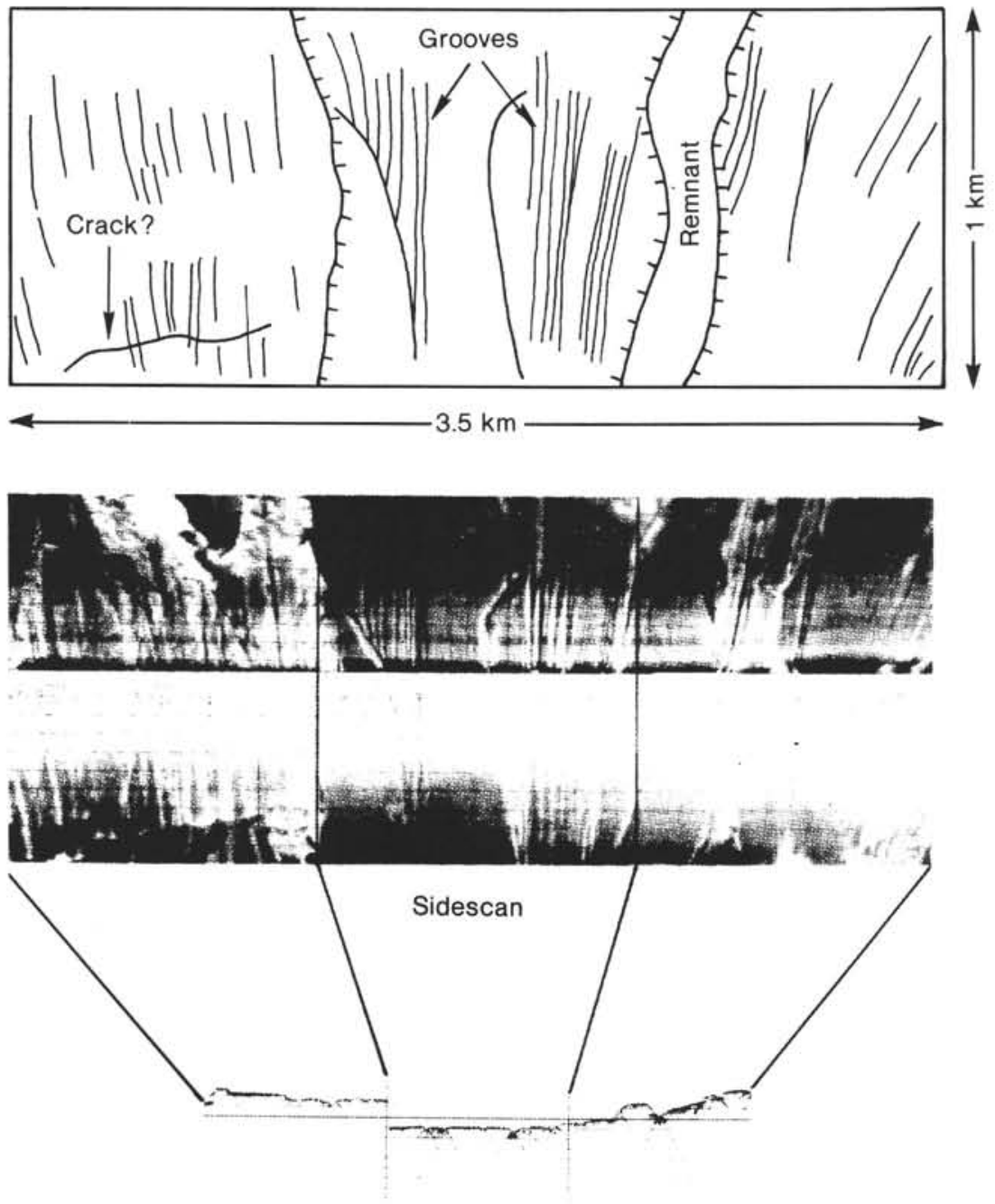

Sub-bottom

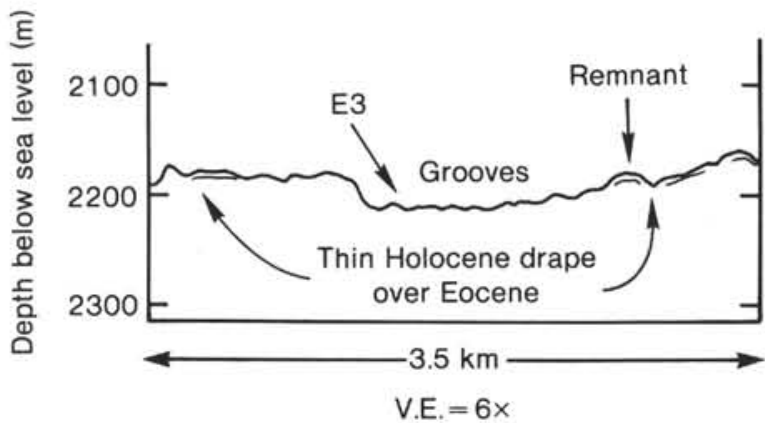

Figure 21. Sea MARC I sidescan/sub-bottom pair: grooved Eocene outcrop on the lower continental slope. The sidescan image illustrates one groove that trends obliquely down the slope that collects at least six other grooves into its path. This morphology is consistent with the mega tool-mark origin for groove formation. We proposed that the groove trending obliquely down the slope captured subsequent blocks of sliding strata, thereby producing the observed structure.

ocene) are draped, stratified sediments that allow significant acoustic penetration (up to $65 \mathrm{~m}$ ) from Sea MARC I's near-bottom 4.5-kHz profiler. Acoustic Unit Q2 occurs where stratified Pleistocene deposits have been eroded and then draped by 1-3 m of Holocene sediment.
The opaque part of the unit, below the Holocene drape, was sampled on the middle slope (at ASP-14), and dated as Pleistocene, although Poag (1985a) does not report whether it is upper or lower Pleistocene. We interpret the reverberent underlying Pleistocene strata of Q2 to be 

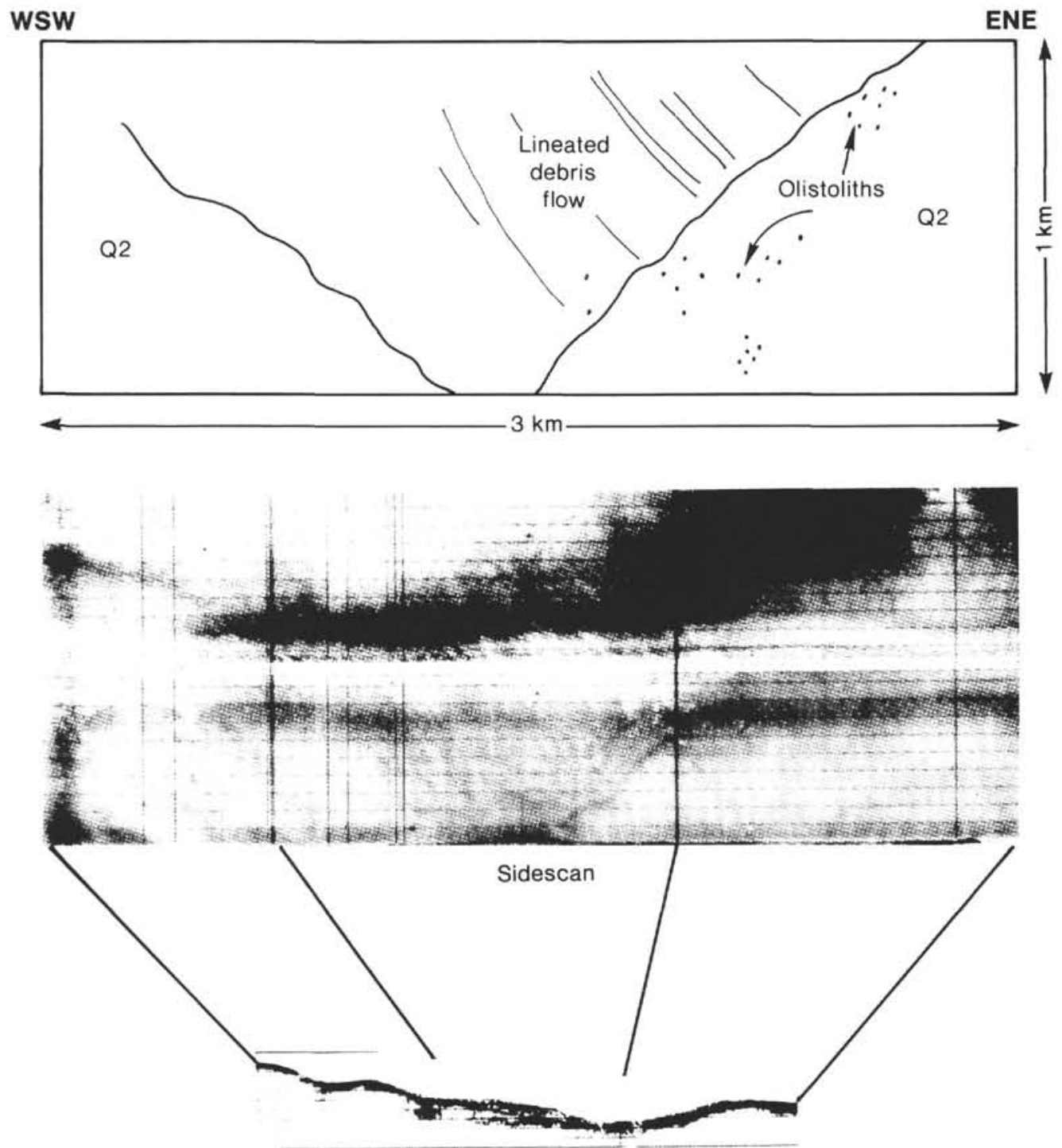

Sub-bottom

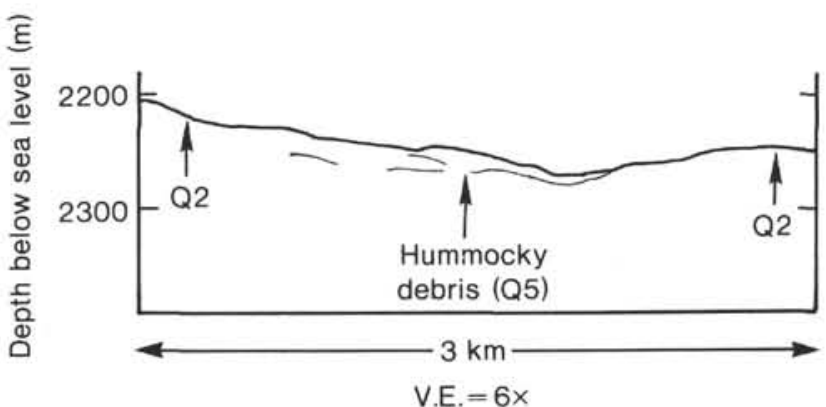

Figure 22. Sea MARC I sidescan/sub-bottom pair showing hummocky, lineated debris flow on the upper continental rise. 


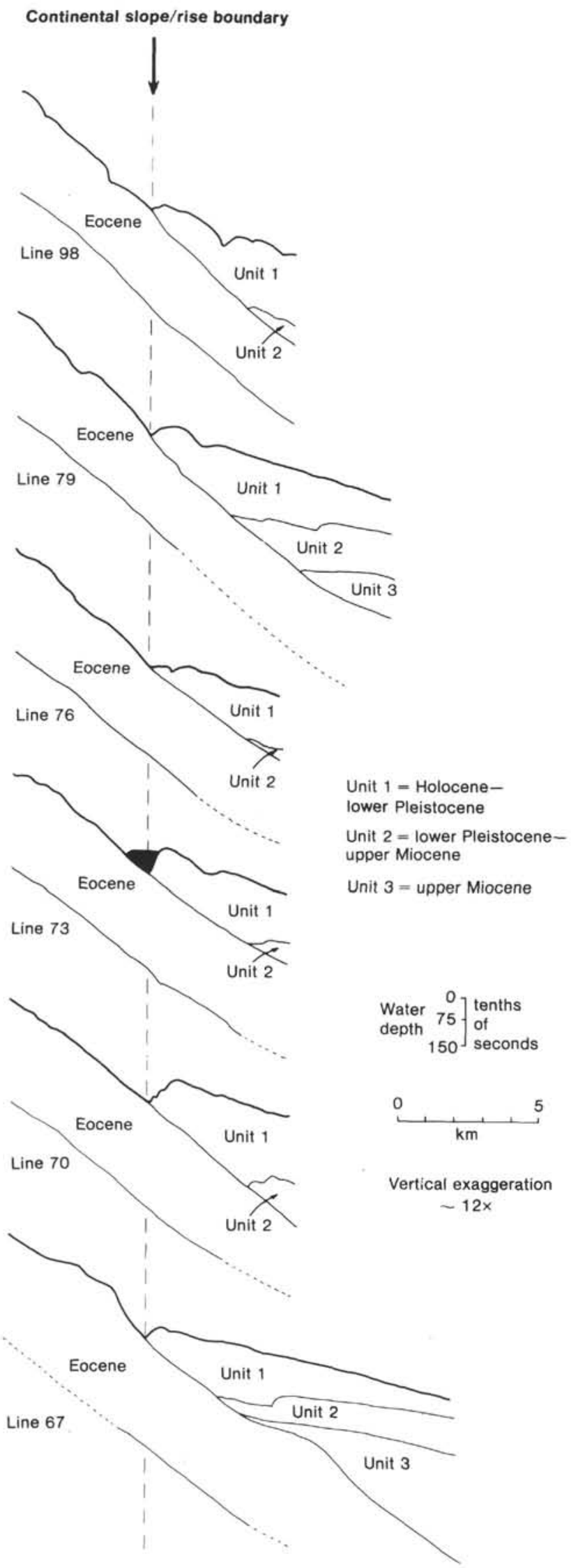

Figure 23. Summary of the variation in morphology along-strike at the slope/rise boundary. older (perhaps lower Pleistocene) than the stratified Pleistocene deposits of Q1 and P1. The boundary separating the stratified and reverberent Pleistocene units on the middle slope may be an expression of a change in lithology with more sand present in the reverberent Pleistocene unit. Strata sampled at ASP-14 (within Q2) did contain sandy layers while the upper Pleistocene strata (within P1, sampled at Site 612) was composed mainly of mud.

Late Pleistocene strata (Q1 and P1) are found across much of the upper slope, but on the middle and lower slope they are found only on downslope-trending spurs flanking the submarine canyons and as isolated patches to the lower slope canyons. The erosional lateral margins of Units P1 and Q1 and their occurrence only on local topographic highs seems to imply that they are erosional remnants of a broader deposit that once draped the entire continental slope. Some canyon crossings show these strata to thin and drape down canyon walls. The observed cross-sectional geometry, with Units P1 and Q1 draping down some canyon walls, can be explained in a scheme where mainly hemipelagic sedimentation affects the entire slope, but significant accumulations develop only on areas not consistently crossed by downslope-directed flows. In this scenario, the tops of the spurs between the submarine canyons are expected to accumulate the thickest hemipelagic deposits, because any downslope-directed flows in their vicinity should pass through the adjacent canyons, not down the spurs. Overbank deposition from suspensions moved by currents down-canyon may contribute toward intercanyon ridge growth (Robb, Hampson, and Twichell, 1981), but we have not seen evidence in our data that the sedimentary layers thin away from the canyons as they should if they were levee-like structures. The more commonly observed situation, where the late Pleistocene strata are abruptly truncated at canyon margins, probably arises as continued canyon erosion, both vertical and lateral, produces oversteepened slopes, and the strata slide into the canyon.

The open slope, west of the three submarine canyons, is not crossed by major valleys on the upper and middle slope. However, the Sea MARC I data show that the area has been subjected to effective downslope-directed erosion. The stratigraphy shows that truncated and gullied deposits of acoustic Units P1 and Q1 cover the area. This setting is consistent with the gradual accumulation of Pleistocene hemipelagic sediment, occasionally interrupted by downslope-directed erosion on the open slope. The pervasiveness of gullied topography within these units at or very near the seafloor argues that late Pleistocene downslope-directed erosion was very effective in beveling this portion of the continental slope.

The observation that the lower slope has retained very little of the inferred late Pleistocene blanket may arise from two or more reasons. If much of the downslopedirected sediment movement originates on the slope (e.g., from sedimentary sliding), then only the lowermost slope would be affected by all the flows and should show signs of most intense erosion. The middle and upper slope would be affected by only those flows originating further upslope. Another factor may be that the late Pleis- 
tocene strata cannot effectively adhere to the major stratal discontinuity marking the top of the Eocene section, and therefore, currents and sediment flows can more easily strip the substrate cover away here, as compared to the thickly sedimented upper and middle slope.

The extremely detailed contouring in the study area provides an unusual opportunity to examine how erosional morphology is affected by the widely changing physical properties of the strata being removed. The gradual trend of V-shaped cross sections on the upper slope towards broader, $\mathrm{U}$-shaped and box-shaped thalwegs on the middle and lower slope apparently correlates with the passage from young, poorly consolidated upper slope cover to resistant, older strata on the middle slope and lower slope. It is reasonable that unconsolidated Pleistocene strata of the upper slope would be more easily downcut by headward erosion and downslope-directed currents into $\mathrm{V}$-shaped valleys with spur and gully side tributaries. Broader, U-shaped and box-shaped profiles develop on the middle and lower slope where older, more consolidated strata resist the downcutting and erosion is forced to spread out laterally, thereby widening the thalwegs.

Other examples of lithology-controlled morphology are the side gullies found in the walls of Lindenkohl Canyon. The stratigraphic analysis indicates that the gullies are confined to carbonate-poor deposits of Miocene and younger age. Side gullies are believed to develop through headward erosion along oversteepened canyon walls through a variety of mass wasting processes (McGregor et al., 1982; Twichell and Roberts, 1982; Farre et al., 1983), but such badland-generating processes can only be effective in producing gullied seascapes in unconsolidated strata possessing no inherent structural fabric.

Although North Carteret Canyon and Northeast Valley die out on the middle-lower slope, Carteret Canyon does extend downslope nearly to the continental rise. As it crosses into the area of exposed Eocene strata, the canyon cross section gradually changes from a $\mathrm{U}$-shaped valley toward a much more rectangular cross section with almost vertical bounding walls and planar floors. The canyon begins to take on many of the same characteristics as the lower slope canyons which are confined to the Eocene section.

\section{Lower Slope Canyons}

Determining the history of development of the lower slope canyons is made difficult by the antiquity of the strata in which they are largely confined. However, the observed structures and stratigraphic relations upslope, within, and downslope of the canyons, do provide some constraints on how and when these canyon systems formed.

On the lower continental slope, where they deeply incise middle Eocene strata, the canyons show ample evidence that their morphology and orientation are structurally controlled. Canyon headwalls and other clifflike scarps within the canyons show remarkably linear and consistent NE/SW and NW/SE trends with orthogonal intersections. The wide, gently seaward-dipping floors and terrace surfaces developed in canyon walls parallel the $\sim 3^{\circ}$ dip of acoustic reflectors observed in seismic profiles within the Eocene section, and these planar surfaces are interpreted to coincide with bedding planes. The observed orthogonal intersections of canyon walls with headland cliff faces, and seafloor observations that show that planar joint surfaces form canyon walls and that tabular slabs of strata lie within canyon thalwegs suggest that the canyons were at least partially excavated by the removal of slabs of strata bound by joint and bedding surfaces.

The structural fabric and overall brittle behavior of the middle Eocene strata may imply that they were formerly buried by a significant overburden prior to canyon formation. It is not known exactly how deep the now-exposed middle Eocene strata were once buried. One can make various estimates based on the seismic data, but such estimates are subject to error because of uncertainties concerning the timing and intensity of post-middle Eocene erosion and on how much the post-middle Eocene section thinned in the seaward direction prior to erosion. Assuming that the middle-upper Eocene section was at one time as thick on the lower slope as it is beneath strike Line 89 , a minimum of $100 \mathrm{~m}$ of overburden removal in intercanyon settings is estimated (Farre, 1985).

Burial followed by significant unroofing may have influenced the physical behavior of the underlying strata. Stresses associated with pressure relaxation (Poisson effects) can lead to formation of vertical joints (e.g., Engelder, 1982) and might have lead to acceleration of exfoliation as the cover was removed. This structural fabric may have exerted a fundamental influence on the development of the lower slope canyons. Intersections of vertical joints with bedding planes accompanied by oversteepened slopes are common in terrestrial rock fall and avalanche source regions (Voight and Periseau, 1978).

The lower slope canyons are fed by sharply defined linear features, which resemble opened cracks within the Eocene strata. These tributaries also follow the NE/SW, NW/SE structural fabric. The structural control and development in carbonate rocks suggest that these tributaries may develop by enlargement of joint surfaces by corrosive $\mathrm{CO}_{2}$-charged ground water escaping the truncated Eocene strata. In such a scenario, recharge for flow would occur along the coastal plain and hydraulic pressures developed during low stands of sea level would power the system (Manheim, 1967). A similar morphology of canyons fed by linear, angular side tributaries called "fretted terrain," is observed on the Martian surface (Sharp, 1973). Fretted terrains are believed to be related to the gradual-to-catastrophic release of once frozen ground water at valley walls along structural trends developed within the Martian regolith (Sharp, 1973; Baker, 1982). It is a process similar to terrestrial valley excavation by ground water sapping (Higgins, 1982). Robb (1984), based on a study of seismic, sidescan, and seafloor observational data, went one step further in concluding that formation of the entire lower slope canyon system may be related to the flow of ground water through the truncated Eocene strata. The main evidences for ground-water-aided erosion are the occurrence in carbonate strata, the 
general morphology of the canyons, and the opened cracks and vertical furrows and other cavities found in the west wall of Lower Slope Canyon A, which seem to be dissolution features within the carbonate rocks. Robb (1984) argues that the canyons could form by retreat of headland cliffs and steep lateral walls, principally by removal of individual grains and dissolution of calcareous grains and matrix. Farre and Ryan (1985b) contend that much of Robb's cited evidence for grain-by-grain valley erosion is also consistent with the previously published hypothesis (Farre et al., 1983) that the canyons are excavated by headward erosion through the removal of slabs of strata along joint and bedding planes from an oversteepened slope.

Another hypothesis that may explain the apparent dissolution features in the Eocene outcrop has been presented by Prior and Doyle (1985). They argue that dissolution of calcareous strata did not result from escaping ground-water, but rather from the corrosive effects of the Western Boundary Undercurrent, which may have impinged higher up on the margin during times of glacial maxima. This hypothesis may explain why large-scale collapse features have not been identified in the sidescan images.

Seismic data show that Lower Slope Canyons B and $A_{W}$ do not continue upslope beneath younger sedimentary cover (Prior et al., 1984). Lower Slope Canyon $A_{E}$, however, may continue upslope beneath upper Miocene and younger strata to the canyon sampled at Site 612 (Farre, 1985). If this is ultimately proved true, it would suggest that Lower Slope Canyon $\mathrm{A}_{\mathrm{E}}$ was at least partially cut prior to or during the late Miocene.

At the continental rise, the relief of the lower slope canyons abruptly decreases, although the canyons do continue, both on the rise surface and excavated into the middle Eocene surface beneath upper rise sediments. The connection with present-day rise valleys suggests significant canyon activity in the late Quaternary. Sidescan data show downslope-trending tracks and trails and olistoliths concentrated in the rise extension of Lower Slope Canyon A, implying downslope transport of material through this canyon in the recent past.

Landward of the lower slope canyons, the continental slope is not incised by large valleys but does show evidence of late Pleistocene downslope-directed erosion, with numerous angular unconformities and gullies developed within draped deposits of Unit Q1 (Farre and Ryan, $1985 \mathrm{~b})$. The rise valleys beneath the lower slope canyons indicate that downslope-directed flows passed through, or originated within, the canyons and have continued as channelized flows across the upper rise during the late Quaternary. The two observations, taken together, imply that downslope-directed mass transport (fluid, slurry, or sliding objects) originating on the upper and/or middle continental slope are captured by the canyons, and these flows might become highly erosive within the confines of the steep-walled excavations. The generally deeper lateral margins of the valleys may be a result of increased gouging and plucking from turbulence and scour near the base of canyon walls. The passage of confined turbidity currents would also explain the polished, rounded, and scalloped outcrop surfaces seen in the canyon walls. Farre and Ryan (1985b) used such reasoning to explain why some areas of the canyon thalwegs are devoid of large allochthonous slabs of strata. Such slabs would be expected to litter the thalwegs if the principal mechanism of valley excavation was slab failure, rock fall, or avalanche (Robb, 1984). Slab failure accompanied by downslope directed transport processes, which carry accumulated debris and also pluck off autochthonous slabs from the canyon floors and walls, can explain the observed erosional structure on the slope landward of the canyons, the joint-controlled, gouged, and polished sidewalls within the canyons, and the valleys which connect with the canyons downslope on the rise. Numerous allochthonous blocks of Eocene strata (some tabular, others well rounded) found on and within the upper rise are also consistent with this mechanism of canyon excavation.

The change from deep incisions on the exposed middle slope to more subdued relief on the Eocene unit, buried beneath the upper rise, occurs without a change in the seaward gradient of the middle Eocene strata. To explain the deeply incised nature of the canyons on the lower slope compared to the subdued topography beneath Pleistocene strata of the onlapping upper continental rise, it would appear that much of the intense canyon cutting occurred during the Pleistocene and perhaps late Pleistocene. This timing would allow the onlapping Pleistocene continental rise to protect the underlying middle Eocene strata from continued excavation from downslope-directed currents. As the flows passed onto the lower gradient continental rise, they lost erosive potential and sediment, and debris deposition began to be a significant process.

The conclusions regarding lower slope canyon development which are well supported by available data are as follows:

1. A significant thickness $(\sim 100 \mathrm{~m})$ of overburden was removed from the middle Eocene section on the lower slope prior to or during the early stages of lower slope canyon formation.

2. A structural fabric within the middle Eocene strata controls canyon morphology.

3. Removal of slabs of strata along joint and bedding planes is a significant contributor to valley excavation. This may occur in catastrophic avalanches and rockslides and/or in gradual, block-by-block processes.

4. Canyon incision may have been initiated as early as late middle Miocene, but the most intense canyon cutting apparently occurred during the Pleistocene.

5. Downslope-directed currents from the upper slope may be captured by the canyons causing accelerated erosion, removal, and transport of sedimentary slabs to the continental rise.

6. Ground-water sapping and corrosion and/or corrosive bottom waters may be significant factors in canyon development. Alternatively, their effects may be latestage overprints on already developed canyon systems.

\section{Grooves}

The origin of the downslope-directed grooves, cut into middle Eocene strata on the lower continental slope near and east of Carteret Canyon is controversial. Ryan 
(1982), from a study of 5-km swath Sea MARC I sidescan images, suggested that the few-meter-deep and wide grooves might be mega-gouge marks formed by sliding blocks of strata. Robb et al., (1983), using the same sidescan data plus observations made from Alvin, argued that three aspects of the grooves were not consistent with the mega-tool mark hypothesis: (1) the parallelism of grooves over areas of irregular topography; (2) the high strength of the calcareous middle Eocene rocks; and (3) the absence of identifiable allochthonous deposits on the upper rise. The formation mechanism favored by Robb et al. (1983) is downslope-directed currents.

Our new data set includes higher resolution $(1 \mathrm{~km}$ swath) sidescan data which show the grooves to be more complex than previously thought. New observations show that although most grooves trend almost directly downslope, four other patterns may occur: (1) some grooves follow curved paths and cross-cut other grooves; (2) single grooves trending obliquely across the slope collect other grooves into single paths; (3) grooves branch up- slope and downslope forming tuning-fork junctions; and (4) some grooves originate at the base of cliffs.

The grooves in the immediate vicinity of lower Carteret Canyon lie only within the 15- to 40-m-deep floors of box-shaped (in cross section) chutes within middle Eocene strata (Fig. 24). This setting implies that the same erosional mechanism that formed the chutes, which we believe to be mass wasting of slabs of strata, also formed the grooves. In fact, all the observations concerning groove morphology can be explained by the mega-tool mark hypothesis. Curved grooves are expected to develop where large blocks acquire spin on their trip downslope during submarine avalanche. Branching can be explained as sliding and rolling blocks either joining or escaping a previously formed groove. Collecting grooves into a single path might occur as blocks slide downslope and join a prominent older groove trending obliquely across the slope. The upslope commencement of grooves at the base cliffs is evidence that the grooves formed as the missing strata tore from the cliff face and slid downslope.

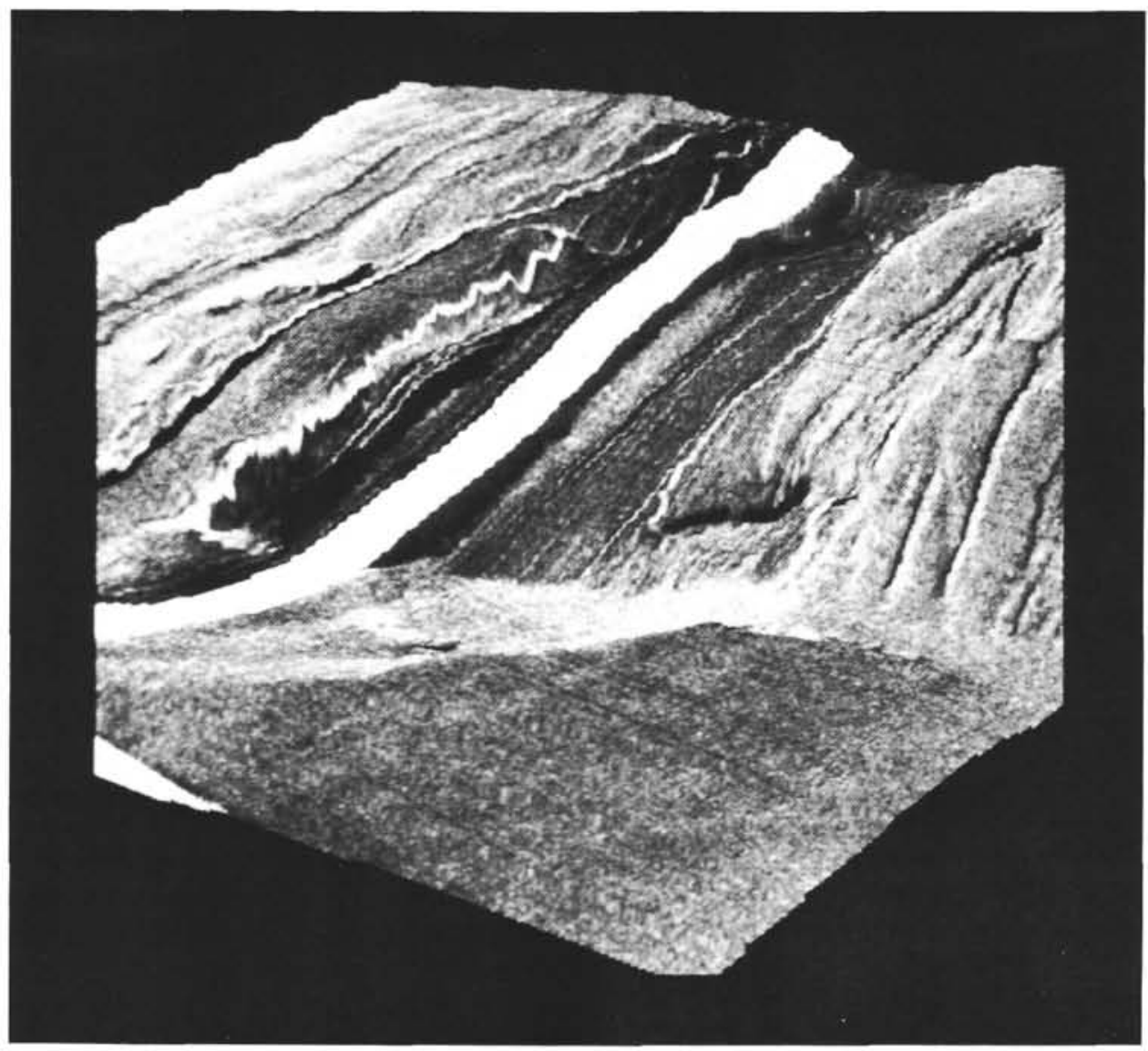

Figure 24. Sea MARC I perspective image of grooved and gullied terrain at the slope-rise boundary, downslope of Carteret Canyon. Vertical exaggeration $=10 \mathrm{X}$. Sidescan image width was $5 \mathrm{~km}$ before projection. 
In support of the mass-wasting origin of grooves, the upper continental rise beneath Carteret Canyon does show allochthonous material (blocks, debris deposits) and Robb, Hampson, and Twichell, (1981) presented evidence of a debris field on the upper rise near South Toms Canyon ( $\sim 10 \mathrm{~km} \mathrm{NE}$ of our study area) downslope of a grooved lower slope. More importantly, drilling data from DSDP Legs 93 and 95 show that displaced slope strata are significant components of the sampled upper continental rise.

Farre and Ryan (1985a) have presented a terrestrial analogy that shows morphology remarkably similar to the submarine grooved landscapes. Slope regions crossed by wet snow avalanches are commonly cut by subparallel, continuous, downslope-directed grooves formed by gouging from the overriding mass (Seligman, 1962; Fig. 25 ). Snow grooves, which show many of the same characteristics (curved paths, cross-cutting, and branching) are rarely, if ever, larger than $1 \mathrm{~m}$ in width or depth. After snow grooves are formed, subsequent, less catastrophic snow flows become channelized and thereby widen and deepen the grooves. Due to the more transient nature of snow-covered slopes, snow grooves may not reach the larger dimensions of their hypothetical submarine analogues.

One of the important joint trends (NW/SE) roughly parallels the downslope direction in the study area and this is also the dominant trend of the grooves. It is possible that downslope-directed flows may be able to exploit and open up weaknesses inherent in the middle Eocene section. This may be a contributing factor in groove formation, but we believe that the other data imply that this process is at best a subordinate contributing factor.

The downslope trend, origin at scar headwalls, occurrence on surfaces co-planar with bedding, and the various cross-cutting relationships all support a formation related to excavation by the removal and sliding of consolidated slope strata. We favor gouging from sliding strata as the primary mechanism of groove formation. It seems likely, considering the absence of significant post-Eocene sedimentary cover on the lower slope, that grooves, once formed by gouging, become enlarged

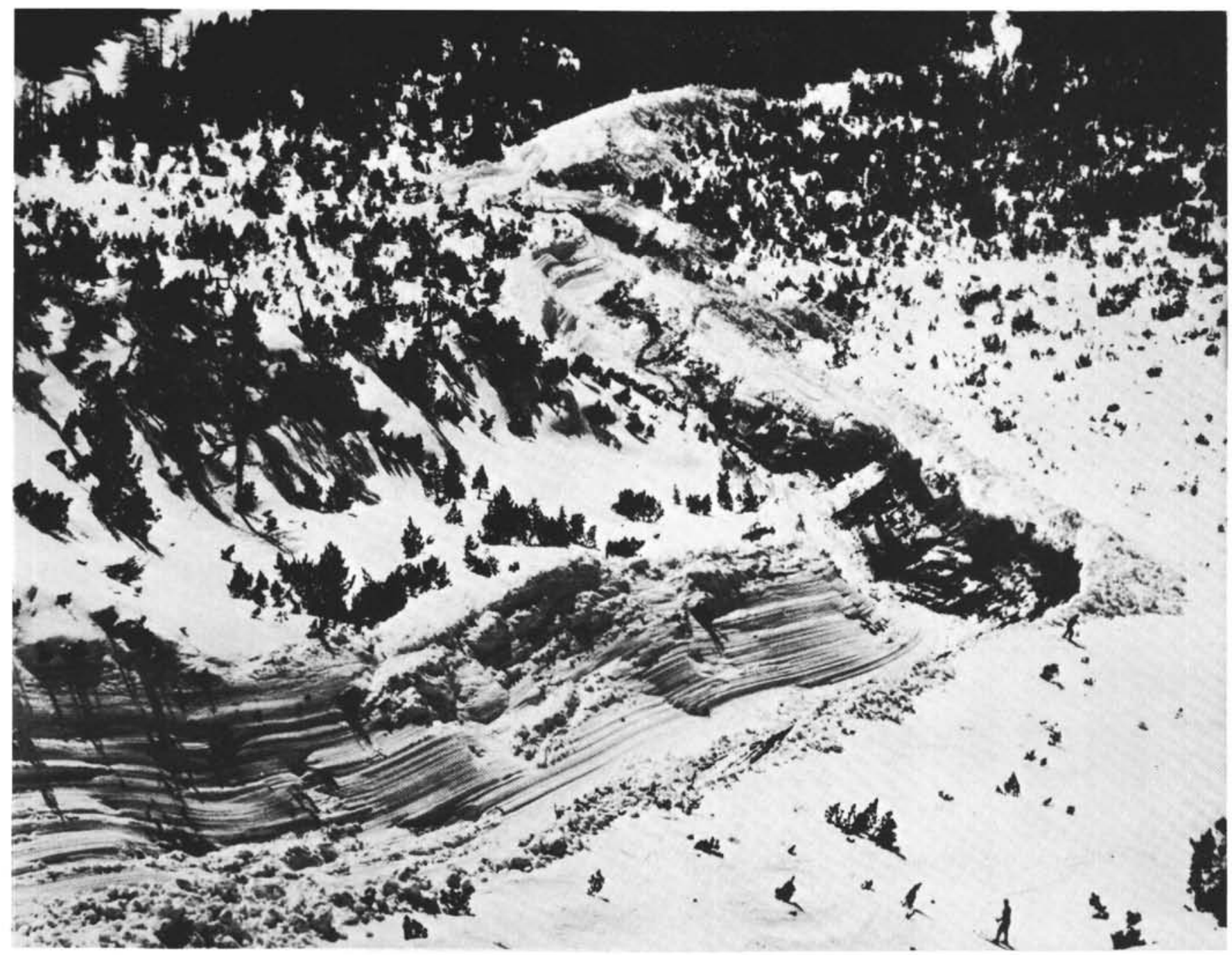

Figure 25. Photograph of snow grooves associated with the passage of a wet snow avalanche. The grooves in the floor of Lower Carteret Canyon and along the eastern lower slope may be submarine analogues formed during rock and sediment slides. From the Avalanche Atlas (1982). 
and modified by other processes including turbidity currents and channelized debris flows.

The timing of groove formation is not well constrained. The upslope disappearance of grooves beneath younger sedimentary cover (Units Q1, Q2, and Q6) and their partial burial beneath Unit $\mathrm{X} 1$ on the lower slope argues that the main period of groove formation occurred in the geological past. As Robb et al. (1983) have suggested, grooves on the lower slope may be relict scars formed between the late Eocene and early Miocene. The setting downslope of Carteret Canyon (see below), however, suggests that grooves may still be forming and/or enlarging in Holocene time.

\section{Continental Rise}

An intriguing aspect of the continental slope/rise boundary is the scattered occurrence along strike of 30to 70-m-deep, 1-to 2-km-wide, 4- to 7-km-long topographic depressions. They are rimmed by $10-$ to $20-\mathrm{m}$-high spurs on their seaward side, and are excavated into the upslope limit of the onlapping continental rise. Three separate depressions lie within the study area. The western-most depression connects with the rise valley extension of Lower Slope Canyon A, but the central depression is an isolated basin. The eastern depression continues to the NE beyond the limit of our data coverage. Portions of all three depressions are found to be partially to fully filled by horizontally stratified sediments.

The fact that the depressions are not continuous features along strike seems to rule out contour-parallel currents as the excavating agent. Sidescan images that cross the westernmost depression, show that the latest event to have affected the area was downslope directed. Olistoliths can be traced seaward along trails $>4.5 \mathrm{~km}$ long down the 1.5 degree incline of the upper rise. Shallow channels and other subtle textural etchings suggestive of flow all trend downslope. Observations from Alvin (Dive 1115) show allochthonous blocks of Eocene chalk from the slope to be strewn across and partially buried within the depression. The Sea MARC I data show a 5- to 15-m-thick transparent debris flow deposit (Unit Q4) lying along much of the slope-rise boundary. The high resolution seismic data show this unit to be the uppermost layer of the 15- to 70-m-thick, horizontally stratified depression fill.

The origin of the depressions is almost certainly related to material moving downslope and encountering the change in gradient $\left(4.5\right.$ to $\left.1.5^{\circ}\right)$ at the slope/rise boundary (Farre and Ryan, 1985a). Base-of-slope depressions with similar dimensions have been described off North Carolina (Bunn and McGregor, 1980) and beneath slope canyons of the steep Malta Escarpment in the Eastern Mediterranean Sea (Cita et al., 1982; Biju-Duval et al., 1983). Mass flow deposits composed of allochthonous slope material have been recovered from the rim of one of the Mediterranean depressions (Cita et al., 1982). Biju-Duval et al. (1983) conclude that dynamic, downslope-directed processes associated with slope valleys are responsible for the formation of depressions beneath the Malta Escarpment. The association of depressions with canyons also holds up reasonably well in our study area: the western depression (dip Lines 67 through 71) lies downslope of Carteret Canyon; there is no depression associated with North Carteret (dip Lines 75 and 76): the middle depression lies downslope of Northeast Valley (dip Lines 77 through 80 and 97); and the eastern depression lies downslope of South Toms Canyon (dip Lines 99,100 , and 104 through 106).

It is not clear how intense the downslope-directed flows that excavate the depressions are and whether excavation is the result of one or many repeated events. The occurrence of empty, partially filled, and completely filled portions of the same depression implies that once a depression is formed, localized debris flows originating on the slope gradually fill them up over time. Areas devoid of sedimentary fill have either been kept open by continued downslope activity, or have not been the site of significant deposition since the time of depression formation.

The sharply defined variations in reflectivity on the upper rise downslope of Carteret Canyon associated with the channels, trails, and allochthonous outrunner blocks, suggest that the mass flow that crossed the area did so in the recent geologic past (several thousand years before present; Farre and Ryan, 1985a). Since a thick ( $>1 \mathrm{~m})$ hemipelagic drape would obscure these well-defined features, an average sediment accumulation rate of $10 \mathrm{~cm} /$ 1000 yr. (Prior et al., 1984), implies that the interval of post flow time is less than 10,000 yr. The continuation of this same depression is filled by $70 \mathrm{~m}$ of horizontally stratified sediment beneath dip Lines 73 and 74 . If the entire depression was excavated within the past 10,000 yr., then a very high debris flow accumulation rate of $>700 \mathrm{~cm} / 1000 \mathrm{yr}$. is required to have filled it to its present state. Alternatively, the depression may be older, formed during the late Pleistocene, and the hypothesized Holocene event, downslope of Carteret Canyon, was not the main excavating event.

\section{The Major Unconformity}

The geologic setting of the upper rise in the study area, with Neogene sediment unconformably overlying much older strata, is similar to the continental rise off Northwest Africa, where lower to middle Miocene massflow deposits overlie lower Cretaceous strata (Arthur et al., 1979).

The stratigraphy of the lower slope and upper rise implies that several erosional episodes cut the slope sometime between the middle Eocene and late Miocene (also see Poag, 1985b; and Poag and Mountain, this volume). Previous work has documented the widespread nature of Oligocene unconformities in the North Atlantic (Rona, 1973; Vail et al., 1977; Tucholke, 1979; Poag and Schlee, 1984; and Miller et al., 1985) and South Atlantic (Supko, Perch-Nielsen, et al., 1977 and van Andel et al., 1978) continental margins and basins. There appear to be at least two different events with different mechanisms that control the formation and distribution of Oligocene unconformities. The common theme, however, is high latitude climatic cooling beginning in the late Eocene (e.g., Shackleton and Kennett; 1975, Savin et al., 1975). The widespread deep-sea unconformities 
$\mathrm{A}^{\mathrm{u}}$ (western Atlantic) and R4 (eastern Atlantic) are believed to have been cut by vigorous, southward flowing bottom currents near the Eocene/Oligocene boundary (Miller and Tucholke, 1983). These currents were probably the result of bottom-water formation in the Norwegian-Greenland Sea and/or Arctic Ocean. It is not known how shallowly the erosive contour currents extended along the U.S. mid-Atlantic margin.

A pronounced mid-Oligocene sea level drop is called upon to explain unconformities identified in shallower paleodepths along widely spaced continental margins (Rona, 1973; Vail et al., 1977; Poag and Schlee, 1984; and Poag, 1985a). Pitman (1977) pointed out that the rate of sea level fall proposed by Vail et al. (1977) is much too rapid to be explained by changes in the rate of seafloor spreading, and that continental glaciation is the only widely accepted mechanism capable of providing such a rapid fall. Recently published oxygen-isotope data support at least three significant ice buildups: earliest Oligocene; early/late Oligocene; and latest Oligocene (Miller and Fairbanks, 1983; Keigwin and Keller, 1984). Miller et al. (1985) argue that the mid-Oligocene sea level fall of Vail et al. (1977) coincides with an approximately $35 \mathrm{~m}$ sea level drop associated with an early/late Oligocene glacial event.

Prior et al. (1984) argued that the geometry of the late Tertiary strata, gradually thinning in the seaward direction, suggested that the middle Eocene strata on the lower slope may have been exposed at least since the end of Miocene time. The gradual thinning of the post-upper Eocene section (Fig. 7) suggests to us that the middle Eocene strata of the lower slope may have been largely exposed since as long ago as sometime in the Oligocene.

One problem is to determine whether the major unconformity exposed on the lower slope and and buried beneath the upper rise is the result of erosion from along- slope boundary currents, downslope-directed currents, or a combination of the two.

The oversteepened state of the lower slope, where the seafloor progressively cuts deeper into the middle Eocene section, could be the product of either downslopedirected or slope-parallel erosion. One possibility is that the margin was significantly eroded by downslope-directed currents associated with the mid-Oligocene sea level low stand. Slope-bypassing processes and accelerated slope erosion are believed to accompany sea level low stands (Vail et al., 1980). Although no Oligocene canyons can be identified within the study area, the seismic and borehole drill data do show evidence for significant Oligocene erosion beneath the upper slope (Farre, 1985). In order to explain the oversteepened state of the lower slope, however, the erosion associated with these downslope-directed currents would have to have been more intense on the lower slope than on the middle slope. Another possibility is that the lower slope was undercut by slope-parallel currents, which filled the western Atlantic basin sometime near the Eocene/Oligocene boundary. This undercutting, as in the case of Northwest Africa, may have been followed by pervasive downslope-directed mass wasting in an attempt for the margin to attain a new equilibrium profile. This removal of material from the slope and redeposition on the rise produces a continental margin with an overall lower gradient. Part of the slope reduction process arises from the onlap of the lower gradient continental rise. As evidenced by the extensive outcrop of middle Eocene strata on the present-day lower continental slope, the margin has yet to reach a configuration conducive to sediment accumulation.

\section{SUMMARY AND CONCLUSIONS}

By the integrated study of Sea MARC I side-scan images, $4.5-\mathrm{kHz}$ near-bottom sub-bottom profiles, high-

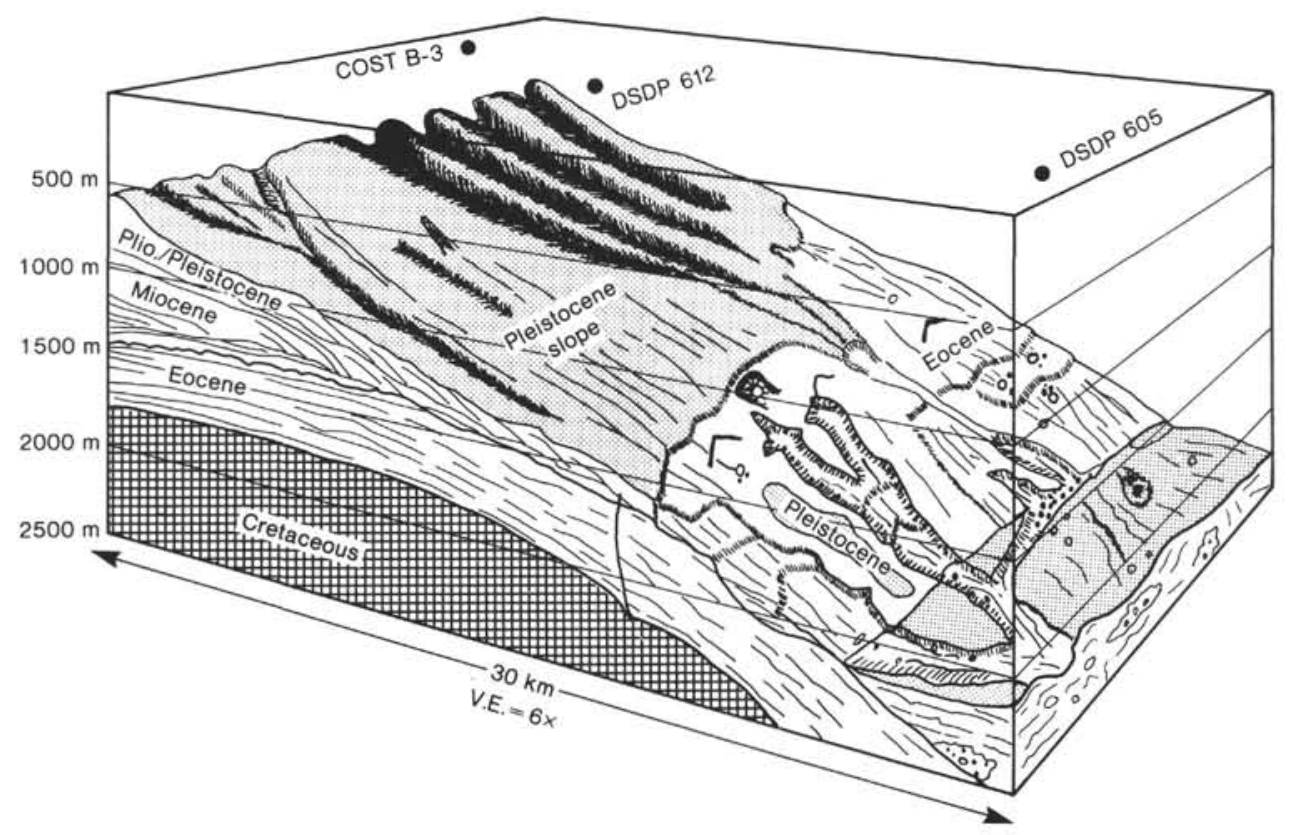

Figure 26. Schematic summary of the surficial morphology and subsurface geology of the study area. 
resolution seismic profiles, and seafloor photographs, calibrated to dated stratigraphic samples, we have documented the present-day morphology and shallow structure of a small segment of the continental margin offshore New Jersey (Fig. 26). Within an only 30 -km-wide margin segment, we have described a broad range of erosional morphologies that are strongly related to the physical properties of the surficial strata.

The modern continental slope is found to be a primarily erosional province, affected mainly by downslopedirected mass movements. Only spurs flanking the submarine canyons have accumulated significant and perhaps nearly complete Quaternary sections on the middle continental slope. The lower slope, with its expansive outcrop of middle Eocene strata, appears to be the product of erosional processes acting over long periods of time. The modern continental rise is a mainly depositional province where displaced shelf and slope strata arrive, sometimes with high energy, and accumulate on its gentle gradients.

If the present-day continental margin offshore New Jersey is at all indicative of ancient passive margins, then it is clear that locations for future drilling programs will have to be chosen very carefully, if sampling of complete stratigraphic sections is desired. The margins of long-lived submarine canyons may be desirable drilling locations, because most downslope-directed and potentially erosive currents tend to pass through canyon thalwegs, thereby allowing canyon margins to accumulate nearly continuous sedimentary sections.

\section{ACKNOWLEDGMENTS}

The acquisition of the Sea MARC I data presented in this chapter required the combined effort of many individuals. Special thanks are credited to D. Chayes, J. Kosalos, J. DiBernardo, A. Malinverno, G. Colley, U. tenBrink, and the captain and crew of the Pacific Seal. Discussions with J. Coleman, E. Doyle, B. Heckler, B. McGregor, D. Prior, and J. Robb were helpful. M. Luckman, E. Kabazares, and P. Tekakjian drafted the figures. Preliminary contouring of Figure 3 was done by J. Hata. The manuscript was reviewed by W. Poag, A. Palmer, and an anonymous reviewer; their comments are gratefully acknowledged. The first author is grateful to the Phillips Petroleum Company for support in the form of a research fellowship.

Data collection was funded by Shell Development Company, Chevron USA, Exxon Co. USA Mobil Research and Development Inc. and Phillips Petroleum Co. This is L-DGO contribution No. 3933.

\section{REFERENCES}

Arthur, M. von Rad, U. Cornford, C., McCoy, F., and Sarntheim, M., 1979. Evolution and sedimentary history of the Cape Bojador continental margin, Northwestern Africa. In von Rad, U., Ryan, W. B. F., et al., Init. Repts. DSDP , 47,Pt. 1:Washington (U.S. Govt. Printing Office), 773-816.

Avalanche Atlas, 1982. International Commission on Snow and Ice of the International Association of Hydrological Sciences. United Nations Educational and Cultural Organization, 7 Place de Fontenoy, 757000 Paris France, p. 265.

Baker, V. R., 1982. The Channels of Mars: Austin, TX (University of Texas Press), p. 198.

Biju-Duval, B., Charier, S., Taviani, M., Morel, Y., Baudrimont, A., Burollet, P. F., Clairefond, P., Clavzon, G., Colantoni, P., Mascle, G., Montadert, L., Perrier, R., Orsoloni, P., Ravenne, C., and Winnock, E., 1983. Dépressions circulariés au pied de l'éscarpment de Malte et morphologie des éscarpments sous-marins: Problems d'interprétation. Rev. Inst. Fr. Pet., 38:605-619.
Bunn, A. R., and McGregor, B. A., 1980. Morphology of the North Carolina continental slope, Western North Atlantic, shaped by deltaic sedimentation and slumping. Mar. Geol., 37:253-266.

Carlson, G. R., 1979. Seismic velocity data and correlation. In Amato, R. V., and Simmons, E. K., (Eds.), Geological and Operational Summary, COST No. B-3 Well, Baltimore Canyon Trough Area, Mid-Atlantic OCS. U.S. Geol. Surv. Open-File Rept., 79-1159: 49-56.

Chayes, D. N., Chezar, H., Farre, J., Rawson, M., Ryan, W. B. F., 1984. New application for ocean bottom survey using submersibles and towed sleds. In Smith, P. F. (Ed.), Underwater Photography, Scientific Photography, Scientific and Engineering Applications: New York (Van Nostrand Reinhold Co.), pp. 121-126.

Cita, M. B., Benelli, F., Bigioggero, B., Bossio, A., Broglia, C., Chezar, H., Clauzon, G., Colombo, A., Giambastiani, M., Malinverno, A., Miller, E. L., Parisi, E., Salvatorini, G., and Vercesi, P., 1982. Unusual debris flow deposits from the base of the Malta Escarpment (Eastern Mediterranean). In Saxon, S., and Nieuwenhuis, J. K., (Eds.), Marine Slides and Other Mass Movements: New York (Plenum Press), pp. 305-322.

Embley, R. W., 1976. New evidence for occurrence of debris flow deposits in the deep sea. Geology, 4:371-374.

Engelder, T., 1982. Is there a generic relationship between selected regional joints and contemporary stress within the lithosphere of North America? Tectonics, 1:161-177.

Farre, J. A., 1985. The importance of mass wasting processes on the continental slope [unpubl. doct. dissert.]. Columbia University, New York.

Farre, J. A., McGregor, B. A., Ryan, W. B. F., and Robb, J. M., 1983. Breaching the shelfbreak: Passage from youthful to mature phase in submarine canyon evolution. In Stanley, D. J., and Moore, G. T. (Eds.), The Shelfbreak: A Critical Interface on Continental Margins. Soc. Econ. Paleont. Mineral., Spec. Publ., 33:25-39.

Farre, J. A., and Ryan, W. B. F., 1983. Are lower slope grooves evidence for large scale submarine mass movement? EOS Trans. Am. Geophys. Union, 64:730 (abstract) , 1985a. A 3-D view of erosional scars on the U.S. mid-Atlantic continental margin. Am. Assoc. Pet. Geol. Bull., 69:923-932. $1985 \mathrm{~b}$. Comment on spring sapping on the lower continental slope, offshore New Jersey. Geology, 13:91-92.

Folger, D. W., Dillon, W. P., Grow, J. A., Klitgord, K. D., and Schlee, J. S., 1979. Evolution of the Atlantic continental margin of the United States. In Talwani, M., Hay, W., and Ryan, W. B. F., (Eds.), Deep Drilling Results in the Atlantic Ocean: Continental Margins and Paleoenvironment: Washington D.C., (Am. Geophys. Union), pp. $87-108$.

Hampson, J. C., Jr., and Robb, J. M., 1984. Geologic Map of the Continental Slope Between Lindenkohl and South Toms Canyons, Offshore New Jersey. U.S. Geol. Surv. Misc. Investigations Map I1608 , scale $1: 50,000,2$ sheets.

Hecker, B., Logan, D. T., Ganderillas, F. E., and Gibson, P. R., 1983. Megafaunal assemblages in Lydonia Canyon, Baltimore Canyon, and selected slope areas. Canyon and Slope Processes study, Final Report from L-DGO to Minerals Management Service, U.S. Bureau of Land Management.

Hollister, C. D., Ewing, J. I., Habib, J., Hathaway, J. C., Lancelot, Y., Luterbacher, H., Paulus, F. J., Poag, C. W., Wilcon, J. A., and Worstell, P., 1972. Site 107, upper continental rise and Site 108, continental slope. In Hollister, C. D., Ewing, J. I., et al., Init. Repts. DSDP, 11: Washington (U.S. Govt. Printing Office) 351-363.

Higgins, C. G., 1982. Drainage systems developed by sapping on Earth and Mars. Geology, 10:147-152.

Keigwin, L. D., and Keller, G., 1984. Middle Oligocene climatic change from equatorial Pacific DSDP Site 77. Geology, 12:16-19.

Kirby, J. R., Robb, J. M., and Hampson, J. C., Jr., 1982. Detailed Bathymetric Map of the United States Continental Slope Between Lindenkohl Canyon and Toms Canyon, Offshore New Jersey. U.S. Geol. Surv. Misc. Field Studies Map MF-1443, scale 1:50,000, 1 sheet.

Klitgord, K. D., and Behrendt, J. C., 1979. Basin structure of the U.S. Atlantic Margin. In Watkins, J. L., Montadert, L., and Dickerson, 
P. W. (Eds.), Geological and Geophysical Investigations of Continental Margins. Am. Assoc. Pet. Geol. Mem., 29:85-112.

Leg 95 Scientific Party, 1984. From the New Jersey Transect: DSDP Leg 95 adds data on the Atlantic Margin. Geotimes, 29(5):14-16.

McGregor, B. A., Stubblefield, W. C., Ryan, W. B. F., and Twichell, D. C., 1982. Wilimington Submarine Canyon: A fluvial-like system. Geology, 10:27-30.

Manheim, F. T., 1967. Evidence for submarine discharge of water on the Atlantic continental slope of South United States and suggestions for further research. N.Y. Acad. Aci. Trans. Ser. 2,, 29:839853.

Miller, K. G., and Fairbanks, R. G., 1983. Evidence for Oligocenemiddle Miocene abyssal circulation changes in the Western North Atlantic. Nature, 306:250-253.

Miller, K. G., Mountain, G. S., and Tucholke, B. E., 1985. Oligocene glacio-eustasy and erosion of the margins of the North Atlantic. Geology, 13:10-13.

Miller, K. G., and Tucholke, B. E., 1983. Development of Cenozoic abyssal circulation south of the Greenland-Scotland Ridge. In Bott, M., Saxov, S., Talwani, M., and Thiede, J. (Eds.), Structure and Development of the Greenland-Scotland Ridge: New York (Plenum Published Corp.), pp. 549-589.

Murray, G. E., 1961. Geology of the Atlantic and Gulf Coastal Province of North America: New York (Harper Brothers).

Pitman, W. C., III, 1977. Relationship between eustasy and stratigraphic sequences of passive margins. Geol. Soc. Am. Bull., 89: 1389-1403.

Poag, C. W., 1985a. Deposition history and stratigraphic reference section for central Baltimore Canyon Trough. In Poag, C. W. (Ed.), Geologic Evolution of the United States Atlantic Margin: New York (Van Nostrand, Reinhold), pp. 217-264.

1985b. Cenozoic and Upper Cretaceous sedimentary facies and depositional systems of the New Jersey slope and rise. In Poag, C. W. (Ed.), Geological Evolution of the United States Atlantic Margin: New York (Van Nostrand, Reinhold), pp. 343-365.

Poag, C. W., and Schlee, J. S., 1984. Depositional sequences and stratigraphic gaps on submerged United States margin. In Schlee, J. S. (Ed.), Interregional Unconformities and Hydrocarbon Accumulation. Am. Assoc. Pet. Geol., Mem., 36:165-182.

Prior, D. B., Coleman, J. M., and Doyle, E. H., 1984. Antiquity of the continental slope along the middle Atlantic margin of the United States. Science, 223:926-928.

Prior, D. B., and Doyle, E. H., 1984. Geological Hazard Surveying for Exploratory Drilling in Water Depths of 2000 Meters. Proc. Offshore Technology Conference, Paper 4747, Houston TX.

, 1985. Intra-slope canyon morphology and its modification by rockfall processes, U. S. Atlantic continental margin. Mar. Geol. 67:177-196.

Rawson, M. D., and Ryan, W. B. F., 1978. (revised 1983). Geological Observation of Deepwater Radioactive Waste Dumpsite-106. Technical Report from L-DGO to Environmental Protection Agency, Washington D. C., 79 pp.

Robb, J. M., 1980. High-resolution seismic-reflection profiles collected by R/V James M. Gillis, Cruise GS 7903-4, in the Baltimore Canyon outer continental shelf area, offshore New Jersey. U.S. Geol. Surv. Open-File Rept., 80-934:3.

1984. Spring sapping on the lower continental slope, offshore New Jersey. Geology, 12:278-282.

Robb, J. M., Hampson, J. C., Jr., Kirby, J. R., and Twichell, D. C., 1981. Geology and potential hazards of the continental slope between Lindenkohl and South Toms canyons, offshore Mid-Atlantic United States. U.S. Geol. Surv. Open-File Rept., 81-600:33.

Robb, J. M., Hampson, J. C., Jr, and Twichell, D. C., 1981. Geomorphology and sediment stability of a segment of the U.S. continental slope off New Jersey. Science, 211:935-937.

Robb, J. M., Kirby, J. R., Hampson, J. C., Jr., Gibson, P., and Hecker, B., 1983. Furrowed outcrops of Eocene chalk on the lower continental slope offshore New Jersey. Geology, 11:182-186.

Rona, P. A., 1973. Worldwide unconformities in marine sediments related to eustatic changes of sea level. Nature Phys. Sci., 244:25-26.
Ryan, W. B. F., 1982. Imaging of submarine landslides with wideswath sonar. In Saxov, S. and Nieuwenhuis, J. K. (Eds.), Marine Slides and Other Mass Movements: New York (Plenum Press) pp. $175-188$.

Savin, S. M., Douglas, R. G., and Stehli, F. G., 1975. Tertiary marine paleotemperatures. Geol. Soc. Am. Bull., 86:1499-1514.

Schlee, J. S., 1981. Seismic stratigraphy of Baltimore Canyon Trough. Am. Assoc. Pet. Geol. Bull., 65:26-53.

Schlee, J. S., Behrendt, J. C., Grow, J. A., Robb, J. M., Mattick, R. E., Taylor, P. T., and Lawson, B. J., 1976. Regional geologic framework off northeastern United States. Am. Assoc. Pet. Geol. Bull., 60:926-951.

Scholle, P. A., 1980. Geological Studies of the COST No. B-3 Well, United States Mid-Atlantic Continental Slope Area. U.S. Geol. Surv. Circ., 833.

Seligman, G., 1962. Snow Structure and Ski Fields: (Belgium) Jos. Adams.

Shackleton, N. J., and Kennett, J. P., 1975. Paleotemperature history of the Cenozoic and the initiation of antarctic glaciation: Oxygen and carbon isotope analysis in DSDP Sites 277 and 281. In Kennett, J. P., Houtz, R. E., et al. Init. Repts. DSDP, 29: Washington (U.S. Govt. Printing Office), 743-755.

Sharp, R. P., 1973. Mars: fretted and chaotic terrains. J. Geophys. Res., 78:4073-4083.

Summerhayes, C., Bornhold, B., and Embley, R. W., 1979. Surficial slides and slumps on the continental slope and rise off southwest Africa. Mar. Geol. 31:265-277.

Supko, P., Perch-Nielsen, K., et al., 1977. Init. Repts. DSDP, 39: Washington (U.S. Govt. Printing Office).

Taylor, D. J., and Anderson, R. C., 1980. Geophysical studies. In Scholle, P. A. (Ed.), Geological Studies of the COST No. B-3 Well, United States Mid-Atlantic Continental Slope Area. U.S. Geol. Surv. Circ., 833:105-110.

Tucholke, B. E., 1979. Relationship between acoustic stratigraphy and Lithostratigraphy in the western North Atlantic Basin. In Tucholke, B. E., Vogt, P. R., et al., Init. Repts. DSDP, 43: Washington (U.S. Govt. Printing Office), 827-846.

Twichell, D. C., and Roberts, D. G., 1982. Morphology, distribution and development of submarine canyons on the United States Atlantic continental margin between Hudson and Baltimore canyons. Geology, 10:408-412.

Vail, P. R., Mitchum, R. M., Jr., Shipley, T. H., and Buffler, R. T., 1980. Unconformities in the North Atlantic. Philos. Trans. R. Soc. London, Ser. A, 294:137-155.

Vail, P. R., Mitchum, R. M., Jr., and Thompson, S., III, 1977. Seismic stratigraphy and global changes in sea level. In Payton, C. D. (Ed.), Seismic Stratigraphy-Applications to Hydrocarbon Exploration. Am. Assoc. Pet. Geol. Mem., 25:83-97.

van Andel, T. H., Thiede, J., Sclater, J. G., and Hay, W. W., 1978. Depositional history of the South Atlantic Ocean during the last 125 m.y. J. Geol., 85:651-698.

van Hinte, J. E., Wise, S. W., Biart, B. N., Covington, J. M., Dunn, D. A., et al., 1985. Deep-sea drilling on the upper continental rise off New Jersey, DSDP Sites 604 and 605. Geology, 13:397-400.

Voight, B., and Pariseau, W. G., 1978. Rockslides: An introduction. In Voight, B. (Ed.), Rockslides and Avalanche I, Natural Phenomenon: Amsterdam, (Elsevier Scientific Publ. Co.), pp. 1-67.

Watts, A. B., 1981. The U.S. Atlantic continental margin: subsidence history, crustal structure and thermal evolution. Am. Assoc. Pet. Geol. Educ. Course Note Ser., 19:1-75.

Watts, A. B., and Steckler, M. S., 1979. Subsidence and eustasy at the continental margin of eastern North America. In Talwani, M., Hay, W., and Ryan, W. B. F. (Eds.), Deep Drilling Results in the Atlantic Ocean: Continental Margins and Paleoenvironment: Washington D.C. (Am. Geophys. Union), pp. 218-234.

Date of Initial Receipt: 31 July 1985

Date of Acceptance: 25 February 1986 